University of Wollongong

Research Online

Faculty of Engineering - Papers (Archive)

Faculty of Engineering and Information

Sciences

$1-1-2008$

\title{
Evaluation of smear zone extent surrounding mandrel driven vertical drains using the cavity expansion theory
}

\author{
lyathurai Sathananthan \\ University of Wollongong \\ Buddhima Indraratna \\ University of Wollongong, indra@uow.edu.au \\ Cholachat Rujikiatkamjorn \\ University of Wollongong, cholacha@uow.edu.au
}

Follow this and additional works at: https://ro.uow.edu.au/engpapers

Part of the Engineering Commons

https://ro.uow.edu.au/engpapers/842

\section{Recommended Citation}

Sathananthan, Iyathurai; Indraratna, Buddhima; and Rujikiatkamjorn, Cholachat: Evaluation of smear zone extent surrounding mandrel driven vertical drains using the cavity expansion theory 2008, 355-365.

https://ro.uow.edu.au/engpapers/842

Research Online is the open access institutional repository for the University of Wollongong. For further information contact the UOW Library: research-pubs@uow.edu.au 
THE EVALUATION OF SMEAR ZONE SURROUNDING MANDREL DRIVEN VERTICAL DRAINS USING THE CAVITY EXPANSION THEORY

\title{
Iyathurai Sathananthan
}

BSc Eng (Hons)

Geotechnical Engineering, Geotechnical Engineer, Coffey Geoscience Pty Ltd, Brisbane, QLD, 4111, Australia.

\section{Buddhima Indraratna}

BSc (Hons), MSc, PhD, DIC, FIEAust., FASCE, FGS

Professor of Civil Engineering, Faculty of Engineering,

University of Wollongong, Wollongong City, NSW 2522, Australia.

\section{Cholachat Rujikiatkamjorn}

BEng (Hons), MEng (AIT), PhD

Research Associate, Civil Engineering Division, Faculty of Engineering, University of Wollongong, Wollongong City, NSW 2522, Australia

\author{
Submitted to: Canadian Geotechnical Journal
}

Author for correspondence:

Prof. B. Indraratna

Faculty of Engineering

University of Wollongong

Wollongong, NSW 2522

Australia.

Ph: +61242213046

Fax: +61 242213238

Email: indra@uow.edu.au 


\title{
The Evaluation of Smear Zone Surrounding Mandrel Driven Vertical Drains using the Cavity Expansion Theory
}

Iyathurai Sathananthan $^{1}$, Buddhima Indraratna ${ }^{2 *}$ and Cholachat Rujikiatkamjorn ${ }^{3}$

\begin{abstract}
In this study, an attempt is made to analyse the extent of the smear zone caused by mandrel driven vertical drains, employing the cavity expansion theory for soft clay obeying the modified Cam-clay model. The predictions are verified by large-scale laboratory tests, where the extent of the smear zone was estimated based on the indications such as the pore pressure generated during mandrel driving, change in lateral permeability and the water content reduction. This study reveals that the radius of smear zone is about 4-6 times the equivalent vertical drain radius, and the lateral permeability (inside the smear zone) is 61$92 \%$ of that of the outer undisturbed zone. Finally, the predicted size of the smear zone using the undrained cavity expansion solution is incorporated in the finite element code PLAXIS to study the performance of a test embankment selected from the Sunshine Motorway, Queensland, Australia. A good agreement between the predicted values and field measurements was found.
\end{abstract}

Keywords: Clay; Ground improvement; Consolidation; Laboratory tests; Case history; Deformation.

\footnotetext{
* Correspondence to : indra@ uow.edu.au

${ }^{1}$ Geotechnical Engineer, Coffey Geoscience Pty Ltd, Brisbane, QLD, 4111, Australia.

${ }^{2}$ Professor of Civil Engineering, Faculty of Engineering, University of Wollongong, Wollongong City, NSW 2522, Australia

${ }^{3}$ Research Associate, Civil Engineering Division, Faculty of Engineering, University of Wollongong, Wollongong City, NSW 2522, Australia
} 


\section{Introduction}

The rapid development and associated urbanization have compelled engineers to construct earth structures, including major highways, over soft clay deposits of low bearing capacity coupled with excessive settlement characteristics. Therefore, it is essential to stabilize the existing soft clay foundations prior to construction in order to avoid excessive and differential settlement. Even though there are a variety of soil improvement techniques available to stabilise the soft ground, the application of preloading with prefabricated vertical drains is still regarded as one of the classical and popular methods in practice. Nevertheless, the installation of vertical drains in the field causes significant remoulding of the subsoil with pore water pressures likely to build up during mandrel driving, especially in the immediate vicinity of the mandrel. The resulting smear zone will have reduced lateral permeability, which adversely affects soil consolidation.

In many classical theories (Barron, 1948; Hansbo 1981), the influence of the smear zone is considered with an idealized two-zone model, i.e., an undisturbed zone with natural permeability and a smear zone with reduced permeability. The accuracy of the predictions using the aforementioned classical theories depends on the correct assessment of the extent of smear zone and the horizontal permeability.

Both the smear zone diameter and its permeability are often difficult to quantify and determine from laboratory and field tests. So far, there is no comprehensive or standard method for measuring them. In the past, for example, Onoue (1988), Indraratna and Redana (1998) and Sharma and Xiao (2000) have conducted laboratory tests to evaluate the smear zone parameters using a specially designed large-scale consolidation test apparatus. Onoue (1988) recommended that the extent of the smear zone can be 4-6 times the equivalent drain radius. Indraratna and Redana (1998) proposed that the estimated smear zone could be as large as 4-5 times the equivalent drain radius and that the horizontal to vertical permeability 
ratio $\left(k_{\mathrm{h}} / k_{\mathrm{v}}\right)$ is close to unity in the smear zone. Sharma and Xiao (2000) proposed that the radius of the smear zone is about four times the equivalent mandrel radius, and the horizontal permeability of the clay layer in the smear zone is approximately 1.3 times smaller than that in the outer (undisturbed) zone.

In this paper, an attempt is made to estimate the extent of smear using the cavity expansion theory (CET) incorporating the Modified Cam-clay model. The theoretical predictions were verified using a fully instrumented large-scale consolidometer. The extent of smear zone in the laboratory was estimated using the variations of lateral permeability and water content, both of which normalized by the corresponding values in the undisturbed zone.

\section{Theoretical Approach to Predict the Extent of the Smear Zone}

Cavity expansion has attracted the attention of many researchers due to its numerous applications in the field of geotechnical engineering (e.g., Vesic, 1972; Atkinson and Potts, 1977; Yu, 2000). Collins and Yu (1996) and Cao et al. (2001) proposed an analytical model of the cylindrical undrained cavity expansion assuming the yielding soil to obey the modified Cam-clay model. In this paper, the extent of the smear zone caused by mandrel driving into soft soil strata is determined on the basis of Cylindrical Cavity Expansion analysis. When a mandrel is driven into the ground, it displaces the soil predominantly outwards in a radial direction. This has led to the drain installation process being modelled as the expansion of a cylindrical cavity with a final radius equal to that of the mandrel $\left(r_{\mathrm{m}}\right)$. In reality, the shapes of mandrel can be rectangular, circular or rhombic, hence the equivalent mandrel radius is evaluated by equating the area between the assumed circular cross-section and the actual shape of mandrel. It is also assumed that soil replaced by mandrel only moves radially in the horizontal direction. 


\subsection{Basic Assumptions and Definition of the Problem}

For the benefit of the readers, a summary of the theoretical background is given in this section (Cao et al., 2001). Fig. 1 shows a cavity with an initial radius $a_{0}$ and an internal pressure $\sigma_{0}$. The cavity expands to a radius of $a$ when the internal pressure increases from $\sigma_{0}$ to $\sigma_{a}$, while an element initially at a radial distance $r_{0}$ from the centre of the cavity moves to a new radial position $r$ from the centre. The soil on the cavity wall will yield when the cavity pressure is sufficiently large, while further increases in cavity pressure will lead to the formation of a plastic zone around the cavity. The radial distance of the plastic zone around the cavity is denoted by $r_{\mathrm{p}}$, while the soil beyond this would remain in a state of elastic equilibrium. Development of analytical framework for analysing cavity expansion is based on the assumption that the soil obeys Hooke's elasticity until the onset of yielding (elastic zone) and the yielding of soil (plastic zone) is described by the Modified Cam-clay model.

The stress ratio $\eta=\frac{q}{p^{\prime}}$ and the radial distance from the centre of cavity $(r)$ can be related by:

$$
\ln \left(1-\frac{r_{m}^{2}}{r^{2}}\right)=-\frac{2(1+v)}{3 \sqrt{3}(1-2 v)} \frac{\kappa}{v} \eta-2 \sqrt{3} \frac{\kappa \Lambda}{v M} f(M, \eta, R) \text { where, }
$$

[1a] $f(M, \eta, R)=\frac{1}{2} \ln \left[\frac{(M+\eta)(1-\sqrt{R-1})}{(M-\eta)(1+\sqrt{R-1})}\right]-\tan ^{-1}\left(\frac{\eta}{M}\right)+\tan ^{-1}(\sqrt{R-1})$

In the above equations, $q$ : deviator stress; $p^{\prime}$ : effective mean pressure; $v$ : Poisson's ratio; $v$ : specific volume; $\Lambda=1-\kappa / \lambda$ : plastic volumetric strain ratio; $\kappa$ : slope of swelling line on $v-\ln p^{\prime}$ space; $\lambda$ : gradient of virgin compression line on $v-\ln p^{\prime}$ space; $M$ : slope of the critical state line; and the isotropic overconsolidation ratio $(R)$ can be related to the conventional overconsolidation ratio OCR as follows (derivation in Appendix 1): 
[2] $R=\frac{3\left(45-12 M+M^{2}\right) \mathrm{OCR}}{(6-M)\left(6+M+2(6-M) \mathrm{OCR}^{\left(\frac{3 M}{6+M}\right)}\right)}$

The radius of plastic zone $\left(r_{p}\right)$ could be found by substituting $\eta=M \sqrt{R-1}$ in Eqn.(1) and the stress ratio $(\eta)$ and the effective mean pressure (p') in the plastic zone can be by:

[3] $p^{\prime}=p_{0}^{\prime}\left[\frac{R}{1+(\eta / M)^{2}}\right]^{\Lambda}$

where, $p_{0}^{\prime}$ is the initial effective mean pressure.

A series representation of effective mean pressure and the deviator stress with radius can be found using the Eqns. 1 and 3. The variation of pore water pressure $(u)$ with the radial distance, when the cavity radius becomes equal to the equivalent mandrel radius, can be obtained from the following equation:

[4] $u=p_{0}+\frac{M p_{0}^{\prime}}{\sqrt{3}} \sqrt{R-1}-\frac{q}{\sqrt{3}}+\frac{2}{\sqrt{3}} \int_{r}^{r_{p}} \frac{q}{r} d r-p^{\prime}$

where, $p_{0}$ is the initial mean pressure.

The authors arbitrarily propose that the extent of the smear zone can be considered as the region in which the pore pressure is greater than the initial overburden stress (total), based on the assumption that the soil is severely disturbed, although the plastic zone may extend beyond this point. The anisotropy with respect to its permeability coefficient is almost entirely destroyed at which $u=\sigma_{v 0}$. A computer subroutine can be used to solve Eqns. (1)(4) in conjunction with the finite element analysis. 


\section{Large-Scale Testing}

\subsection{Test Apparatus}

The large-scale radial drainage consolidometer consists of two cylindrical (stainless steel) half sections, each of which has a flange running the length of the cylinder so that they can be bolted together. The dimensions of the cell are: $650 \mathrm{~mm}$ (internal diameter) $\times 1040 \mathrm{~mm}$ (height) $\times 8 \mathrm{~mm}$ (thickness), and it has a $1.5 \mathrm{~mm}$ thick Teflon sleeve fitted around the internal cell boundary to reduce friction. The bolted cell (Fig. 2a) is mounted on a steel base. The loading can be applied by an air jack compressor system via a piston. An LVDT is placed on top of the piston to monitor surface settlement, and strain gauge type pore pressure transducers are also installed to measure the pore water pressures at various depths. In addition, an array of strain gauge type pore pressure transducers with saturated tips (T1-T5) are installed radially at a depth of $0.5 \mathrm{~m}$ from the top surface (Fig. 2b), to monitor the pore pressure development during mandrel driving.

\subsection{Testing Method}

The preparation of clay sample, installation of the prefabricated vertical drain and the collection of samples at the end of consolidation to measure the permeability and water content are the main steps involved in this test. Given the dimensions of the large cell (650 $\mathrm{mm}$ diameter and 950mm height, it was almost impossible to obtain undisturbed samples of this size. Therefore, commercially available reconstituted alluvial Moruya clay was used to prepare the samples. The Moruya's clay properties were described elsewhere by Indraratna and Redana (1998). First, the clay was thoroughly mixed with water and kept in a closed container for several days to ensure full saturation. Then the cell was filled with the soft reconstituted clay in $150 \mathrm{~mm}$ layers, with light vibration to expel any trapped air before adding the next layer to raise the total height to $950 \mathrm{~mm}$. After specimen preparation, a layer 
of filter cloth was placed on the clay surface followed by the top plate. Subsequently, the load cell was installed on top of the plate to measure the applied load from the pressure chamber and the pore pressure transducers were installed at the specific radial distances (Fig. 2b). Subsequently, a predetermined initial preconsolidation pressure $(20-50 \mathrm{kPa})$ was applied prior to drain installation.

The prefabricated vertical band drain $\left(100 \times 4 \mathrm{~mm}^{2}\right)$ was installed at a rate of $0.5 \mathrm{~m} / \mathrm{min}$ using a specially designed $125 \mathrm{~mm} \times 25 \mathrm{~mm}$ rectangular mandrel. The mandrel radius based on the equivalent area $\left(r_{\mathrm{m}}\right)$ is $31.5 \mathrm{~mm}$. The end of the drain was attached to a $135 \mathrm{~mm} \times 35$ mm rectangular 'shoe' to ensure that the drain remained anchored in the predetermined depth when the mandrel was withdrawn. The consolidation pressure was applied in stages up to a maximum of $200 \mathrm{kPa}$. Finally, at the completion of consolidation, soil specimens $(100 \mathrm{~mm}$ diameter and $50 \mathrm{~mm}$ thickness) were collected at different vertical and radial locations (Fig. 2c) to carry out the permeability and water content determinations. The details of the permeability test method can be found elsewhere by Indraratna and Redana (1998) and Sharma and Xiao (2000).

\subsection{Verification of the Solution using Large-Scale Laboratory}

\section{Comparison of pore water pressure variation during mandrel installation}

Pore pressure transducers, T1-T5 having a distance from the centre of 125, 135, 155, 185 and $250 \mathrm{~mm}$, respectively, were installed $0.5 \mathrm{~m}$ below the surface to measure the variation of the pore pressure during installation (Fig. 2b). The expected pore pressure variation during mandrel driving and withdrawal is shown in Fig. 3, while the measured pore pressure variation for each initial surcharge pressure is plotted in Fig. 4. The pore pressure response shows an increase in magnitude until the maximum value, which occurs when the mandrel tip

just passes the depth at which the transducers are located. The pore pressure continues to 
drop as the mandrel is driven deeper. Subsequently, the pore pressure drops rapidly and then converges to a small residual value when the mandrel is withdrawn. As expected, the magnitude of pore pressure decreases with the radial distance, the data measured by $\mathrm{T} 1$ (closest to the mandrel) being the highest and T5 the lowest.

In order to determine the extent of the smear zone, normalized pore pressure (i.e., pore pressure / initial overburden stress) was plotted against the normalized radial distance (i.e., radial distance / equivalent mandrel radius). In Fig. 5, the maximum normalized pore pressure at the location of each transducer is compared with the predicted normalized pore pressure based on the CET solution. The modified Cam-clay parameters used in this analysis are given in Table 1 (Indraratna et al., 2004). The predicted pore pressure ratios are very close to those measured, and the predicted extent of the smear zone is $2.41,2.46,2.61$ and 2.63 times the equivalent mandrel radius, corresponding to the four different initial surcharge pressures of 20, 30, 40 and $50 \mathrm{kPa}$, respectively.

Sharma and Xiao (2000) employed a large-scale test consolidometer with $1 \mathrm{~m}$ internal diameter and $0.4 \mathrm{~m}$ high to examine the smear zone characteristics around circular vertical drain. In this study, the reconstituted clay was subjected to preloading pressure of $100 \mathrm{kPa}$. The predicted and measured normalised pore pressures are shown in Fig. 6a. The predicted smear zone radius is approximately 4.1 times the mandrel radius, whereas the observed smear zone radius estimated from the horizontal permeability variation by Sharma and Xiao (2000) is about $100 \mathrm{~mm}$ or 3.7 times the mandrel radius. Based on the large-scale laboratory tests, for 100kPa preloading pressure, Sharma and Xiao (2000) determined the extent of smear zone to be at least 3.7 times the mandrel radius. This suggests without doubt that the extent of smear zone depends on the surrounding soil properties and the loading history. 


\section{Prediction of smear zone based on the variation of normalized permeability}

At the end of large-scale consolidation test, horizontal and vertical specimens were collected at $0.5 \mathrm{~m}$ below the surface to measure the coefficient of permeability. Variation of the normalized lateral permeability $\left(k_{\mathrm{h}} / k_{\mathrm{hu}}\right)$ for different mean applied consolidation pressures is plotted in Fig. 7a. The lateral permeability was determined as the average of the values measured along the short and long axes of the drain (see Fig. 2c). It clearly shows that close to the drain, the $k_{\mathrm{h}} / k_{\mathrm{hu}}$ ratio decreases rapidly (highly disturbed zone), whereas further away the effect of mandrel on soil disturbance becomes insignificant. From this data, it can be concluded that the minimum extent of smear zone is about 2.5 times the equivalent mandrel radius. Also, the lateral permeability within the smear zone varies from $61-92 \%$ (an average of $75 \%$ ) of undisturbed zone permeability.

\section{Prediction of smear zone based on normalized water content reduction}

Past research confirms that permeability is dependent upon both void ratio and the water content of the soil (e.g. Taylor, 1948; Tavenas et al. 1983a,b; Babu et al. 1993). Therefore, it is logical to argue that the driving of mandrel not only affects the horizontal coefficient of permeability but also the water content. In this paper, an attempt is made to evaluate the extent of smear zone also from the variation of normalized water content reduction measured along the short and long axes of the PVD, i.e., $\left(w_{\max }-w\right) / w_{\max }$. Figure $7 \mathrm{~b}$ shows that all average measurements are confined within a narrow band, and clearly demarcating the smear zone from the relatively undisturbed outer zone. Based on this plot, the extent of smear zone can be estimated to be around 2.5 times the equivalent mandrel radius. This agrees well with the estimated extent of smear zone based on $k_{\mathrm{h}} / k_{\mathrm{hu}}$ ratio discussed earlier (Fig. 7a). These results are also in agreement with the CET predicted smear zone as previously presented in Fig. 5. 


\section{Application of CET Solution to a Selected Case History}

The Sunshine Coast is one of Australia's fastest growing regions and the continued economic and population growth has increased the pressure on the region's main traffic corridor, the Sunshine Motorway. Site investigation at the proposed development route revealed that the subsoil consists of highly compressible, saturated marine clays of high sensitivity. In order to evaluate the effective ground improvement techniques, a fully instrumented trial embankment was constructed in 1992 and monitored by the Queensland Department of Main Roads (QDMR), Brisbane.

The subsoil conditions are relatively uniform throughout the site, consisting of silty or sandy clay about $10-11 \mathrm{~m}$ thick, overlying a layer of dense sand approximately $6 \mathrm{~m}$ thick. The $\lambda /\left(1+e_{0}\right)$ of the subsoil varies from 0.19 to 0.63 , and the $\kappa /\left(1+e_{0}\right)$ was found to be about 10 times smaller than the compression index (QDMR, 1991).

The base area of the trial embankment was approximately $90 \mathrm{~m} \times 40 \mathrm{~m}$ and incorporated 3 separate sections (Fig. 8a), identified as Sections A, B, and C, respectively. Sections A and B (each $35 \mathrm{~m}$ in long) represented the zones of prefabricated vertical drains (installed at $1 \mathrm{~m}$ intervals) and 'no drains' respectively. Vertical prefabricated drains were installed at a spacing of $2 \mathrm{~m}$ in Section C. These prefabricated vertical drains (Nylex Flodrain, $100 \times 4 \mathrm{~mm}^{2}$ ) in Sections $\mathrm{A}$ and $\mathrm{C}$ were installed in a triangular pattern.

A working platform $0.65 \mathrm{~m}$ thick $(500 \mathrm{~mm}$ thick drainage layer composed of $7 \mathrm{~mm}$ size gravel, plus $150 \mathrm{~mm}$ of selected fill) was placed on top for construction traffic access. Prefabricated vertical drains (PVD) were installed from the working platform to a depth of $11 \mathrm{~m}$ at Sections A and C. The embankment was constructed in stages using a loosely compacted granular material $\left(\gamma_{\mathrm{t}} \approx 19 \mathrm{kN} / \mathrm{m}^{3}\right)$ up to a height of $2.3 \mathrm{~m}$. Two berms, $5 \mathrm{~m}$ in width on the instrumented side and 8m wide on the other side (Fig. 8) were constructed to increase 
the stability of the embankment. Half of the cross-section was intensively instrumented to capture the foundation response upon loading. Typical cross-section of embankment with selected instrumentation points is shown in Fig. 8b. In this paper, the deformation and pore water pressure responses below Sections A, B and C were predicted using a plane strain finite element analysis and then compared with the available field data.

The multi-drain plane strain analysis was carried out using the finite element code PLAXIS, where the soil layers were divided into many elements. The soft soil model based on Modified Cam-clay theory was used to analyse the behaviour of clay layers. The laboratory determined soil parameters used by the authors in the finite element analysis are given in Tables 2 and 3 (QDMR, 1991). In this paper, the soil layer close to the surface was modelled using the modified Cam-clay (MCC) properties determined by QDMR (1991). Given that the soil beneath the surface (up to $2.5 \mathrm{~m}$ depth) is only lightly overconsolidated $(\mathrm{OCR}=1.6)$, the authors have assumed that the application of MCC parameters for this soil layer is valid. It is noted that for situations where the surface soil is heavily overconsolidated (compacted crust), the use of MCC parameters is inappropriate.

\subsection{Variation of Extent of Smear Zone}

As there was no smear zone measurement in the field, the extent of the smear zone with depth was predicted using the CET solution, incorporating the Modified Cam-clay parameters given in Table 2 . The predicted normalised pore water pressure $\left(u / \sigma_{\mathrm{v} 0}\right)$ variation with radial distance for each soil layer is shown in Fig. 9a. The CET predicted extent of the smear zone (i.e., the distance from the centreline at which $u / \sigma_{v 0}=1$ ) is illustrated in Fig. $9 b$, which shows that the smear zone decreases from $6.6 r_{\mathrm{w}}$ to $4.9 r_{\mathrm{w}}(\approx 230-170 \mathrm{~mm})$ when the depth increases from 0 to $11 \mathrm{~m}$. 


\subsection{Plane Strain Conversion}

For construction sites with a large number of PVDs, two-dimensional (2D) plane strain conversion is the most convenient with regards to computational efficiency. It is far less time consuming than a three-dimensional (3D) multi-drain analysis with each drain having its own axisymmetric zone, which substantially affects the mesh complexity and the corresponding overall convergence. Therefore, to employ a realistic 2D plane strain analysis, the appropriate equivalence between the plane strain and axisymmetric analysis needs to be established in terms of consolidation settlement. In the analysis described here, the equivalent plane strain permeability in the undisturbed zone $\left(k_{\mathrm{hp}}\right)$ was estimated using the following equation (Indraratna and Redana, 2000):

$[5] \frac{k_{h p}}{k_{h}}=\frac{\frac{2}{3}\left(1-\frac{1}{n}\right)^{2}}{[\ln (n)-0.75]}$

where, $k_{\mathrm{h}}$ :axisymmetric permeability; and $n=B / b_{\mathrm{w}}$ : spacing ratio.

Indraratna and Redana (2000) assumed that the permeability within the smear zone is reduced but constant, however, laboratory results indicate that the permeability varies with the radial distance (Fig. 7a). In the analysis described here, the smear zone permeability $\left(k_{h p}^{\prime}\right)$ was assumed to vary in a parabolic manner that fits the laboratory test, as given below:

[6] $\frac{k_{h p}^{\prime}(x)}{k_{h p}}=\left[1-\left(1-r_{\mathrm{k}}\right)\left(\frac{b_{\mathrm{s}}-x}{b_{\mathrm{s}}-b_{\mathrm{w}}}\right)^{2}\right] \quad b_{\mathrm{w}} \leq x \leq b_{\mathrm{s}}$

where, $b_{\mathrm{w}}, b_{\mathrm{s}}$, and $B$ are equivalent half width of drain, smear zone and the plane strain cell, respectively; $r_{\mathrm{k}}=2$ is the permeability ratio: $k_{h p}^{\prime}\left(x=b_{\mathrm{w}}\right) / k_{h p}^{\prime}\left(x=b_{\mathrm{s}}\right)$ in the smear zone.

The equivalent plane strain permeabilities based on Eqns. (5) and (6) are given in Table 3. 


\subsection{Numerical Prediction and Comparison with Field Data}

The finite element (PLAXIS) mesh, which contains 15-node triangular elements, is shown in Fig. 10. The entire width of embankment had to be modelled because the loading was not symmetrical. The prefabricated vertical drains were modelled with zero thickness drain elements (the excess pore pressure along this element is zero). The smear zone was modelled with the same modified Cam-clay properties $\left(\lambda /\left(1+e_{0}\right), \kappa /\left(1+e_{0}\right), M\right)$ as the adjacent zone except for the reduced coefficient of lateral permeability based on Eqn. 6. The locations of instruments were conveniently placed in the mesh in such a manner that the measuring points coincided with the mesh nodes. Only $11 \mathrm{~m}$ depth of the foundation was considered due to the existence of the dense sand layer (below the overlying soft clay layer), which was stiff enough to assume a non-displacement boundary. Both the top (open boundary) and bottom surfaces of the subsoil foundation were assumed to be free draining and the water table coincided with the ground surface. Embankment loading history is shown Fig. 11.

The settlement gauges under Sections A, B and C, namely, SCA1, SCB3 (both under the centreline) and SCC5 (1m to the left of centreline) were selected for the purpose of comparing the field data with the numerical results. The predicted and measured surface settlements are illustrated in Fig. 12, which shows that the predicted values are in good agreement with the field data for Sections B and C. As expected, the rate of settlement increases due to the PVDs, where the settlement at Section B (no drain) is only about $60 \%$ of that at Section A (drains at $1 \mathrm{~m}$ spacing). This proves that the installation of vertical drains significantly decreases the consolidation time for a given settlement, improving the soil substantially within months rather than years. Generally, the settlement rate is expected to be sensitive to drain spacing, but in this study, the difference in settlement-time plots for Sections A and C is small. This is because, the installation of closely spaced drains at Section A causes greater smear compared to at Section $\mathrm{C}$ as well as possible lateral variation of soil 
properties. In the finite element analysis, the soil properties are assumed constant along any lateral plane. For example, the total width of smear zone at Section A (drains @1m spacing) is about $18.9 \mathrm{~m}$ compared to $9.7 \mathrm{~m}$ at Section C (drains @2m spacing). This demonstrates that reducing the drain spacing excessively may only provide a marginal advantage due to increased smear.

Lateral deformation measured by the 3 inclinometers (IA2, IB4 and IC5) installed at the toe of the $5 \mathrm{~m}$ wide berm at Sections A, B and C are compared with the numerical predictions in Fig. 12. As expected, the vertical drains significantly curtail the lateral deformation. For example, at $1 \mathrm{~m}$ below the surface, the PVD's installed at 1m spacing (Section A) reduced the lateral displacement by $21 \%$ compared to Section B (no drains) and by $6 \%$ compared to Section $\mathrm{C}$ (drains installed at $2 \mathrm{~m}$ spacing). These results also indicate that the predicted lateral displacement represents an acceptable match with the field data, but in some plots, a noticeable discrepancy is found approaching the ground surface within the upper most, lightly overconsolidated silty clay $(\mathrm{OCR}=1.6)$. For Section A plots (after 100 days) near the surface, the observed field displacements are larger than the predictions, even though the soil is lightly overconsolidated. This may suggest that the closely spaced drains at $1 \mathrm{~m}$ spacing may have caused excessive smear. This is also supported by the observed excess pore water pressure as discussed below.

The predicted and observed variations of excess pore pressure at selected points beneath the middle of the berm are shown in Fig. 13. The selected pneumatic piezometers PPA13, PPB31 and PPC43 were installed at a depth of 5.0m at Sections A, B and C, respectively. Fig. 13 shows that significant excess pore pressures were generated due to embankment loading, and the predictions are in very good agreement with the field data. As expected, the induced excess pore pressure at Section B (no drains) is significantly higher (approximately 30\%) than the other sections. Surprisingly, it is observed that at Section A 
where the drains are closely spaced, the excess pore water pressure is either slightly higher or nearly the same as at Section C. This can be attributed to excessive smear at Section A causing retarded pore pressure dissipation.

\section{Conclusions}

In this paper, an analytical solution based on the cavity expansion theory (CET) incorporating the modified Cam-clay model was employed to determine the size of the smear zone. It is postulated that within the smear zone the normalized pore pressure $u / \sigma_{\mathrm{v} 0}$, (i.e., pore pressure / initial overburden stress) exceeds unity. The predicted smear zone was verified using largescale consolidometer testing on the basis of pore water pressure development during mandrel installation, the variation of normalized permeability $\left(k_{\mathrm{h}} / k_{\mathrm{hu}}\right.$ ratio), and the reduction of normalized water content. Generally a good agreement between the predictions and measurements was found. The results indicated that the extent of the smear zone was at least 2.5 times the equivalent mandrel radius and the smear zone permeability varies from $61-92 \%$ (average of $75 \%$ ) of the undisturbed zone permeability.

The CET solution was applied to a trial embankment from Sunshine Coast, and it was found that the extent of smear zone varied from about 5.0-6.5 times the equivalent drain radius. The performance of the trial embankment was analysed using a 2D multi-drain (plane strain) finite element analysis employing PLAXIS. The effect of smear associated with the installation of PVD was considered, while the effect of well resistance was neglected because the discharge capacity of PVD was large enough, and also they were stiff enough to prevent 'kinking' during installation. The smear zone permeability was assumed to vary with radial the distance in a parabolic manner (see Fig. 6a, and Eqn. 6) and incorporated in the finite element analysis. 
The predicted centreline settlement, excess pore water pressure beneath the berm, and the lateral movements at the embankment toe were compared with the available observed data. Good agreement between the predicted and measured data was generally found, except for the lateral displacements approaching the surface (lightly overconsolidated silty clay, OCR=1.6). The predicted and measured lateral movements showed that the installation of vertical drains curtailed the lateral displacement, thereby decreasing the risk of shear failure. The settlement response of the embankment sections indicated that the installation of vertical drains significantly decreased the consolidation time, whereas the benefits derived from installing vertical drains at closer spacing $(1 \mathrm{~m})$ as compared to a greater spacing of $2 \mathrm{~m}$ were marginal. Too close drain spacing invariably contributes to increased smear thereby decreasing the rate of pore pressure dissipation. Therefore, installing PVD's too closely may not always provide a significant advantage in terms of consolidation achieved. 


\section{Appendix 1: Relationship between Isotropic and Conventional Overconsolidation Ratio}

To properly account for the effect of initial stress condition, one needs to differentiate between the overconsolidation ratio defined in terms of either the vertical effective stress or the mean effective stress. The isotropic overconsolidation ratio $(R)$ is defined as the ratio of maximum stress on yield locus $\left(p_{c 0}^{\prime}\right)$ and the in situ mean effective stress $\left(p_{0}^{\prime}\right)$, hence,

[A1] $R=\frac{p_{c 0}^{\prime}}{p_{0}^{\prime}}$

The conventional overconsolidation ratio, OCR, is defined in the one-dimensional condition as the ratio of the vertical preconsolidation stress $\sigma_{\mathrm{vmax}}^{\prime}$ and the in situ effective vertical stress $\sigma_{\mathrm{v} 0}^{\prime}$, hence,

[A2] $\mathrm{OCR}=\frac{\sigma_{\mathrm{vmax}}^{\prime}}{\sigma_{\mathrm{v} 0}^{\prime}}$

The in situ mean effective stress is usually related to the in situ effective vertical stress by:

[A3] $p_{0}^{\prime}=\frac{1}{3}\left(1+2 K_{0}\right) \sigma_{\mathrm{v} 0}^{\prime}$

where, $K_{0}$ is the coefficient of earth pressure at rest, that can be approximated by (Mayne and Kulhawy, 1982)

[A4] $K_{0}=K_{0 \mathrm{nc}} \mathrm{OCR}^{\sin \phi}$

where, $\phi^{\prime}$ : effective friction angle; $K_{0 \mathrm{nc}}$ : the value of $K_{0}$ for a normally consolidated soil that can be estimated from the well known expression (Jaky, 1944):

[A5] $K_{0 \mathrm{nc}}=1-\sin \phi^{\prime}$ 
When $\sigma_{\mathrm{v} 0}^{\prime}$ reaches $\sigma_{\mathrm{vmax}}^{\prime}$, the maximum past mean effective stress $p_{\mathrm{m}}^{\prime}$ becomes:

[A6] $p_{\mathrm{m}}^{\prime}=\frac{1}{3}\left(1+2 K_{0 \mathrm{nc}}\right) \sigma_{\mathrm{vmax}}^{\prime}$

The corresponding deviator stress $q_{\mathrm{m}}$ is given by:

[A7] $q_{\mathrm{m}}=\left(1-K_{0 \mathrm{nc}}\right) \sigma_{\mathrm{vmax}}^{\prime}=\sin \phi^{\prime} \sigma_{\mathrm{vmax}}^{\prime}$

Substituting Eqns. (A6) and (A7) into the MCC equation, the $p_{c 0}^{\prime}$ can be found as:

[A8] $p_{c 0}^{\prime}=\left[\frac{9\left(1-K_{\mathrm{onc}}\right)^{2}+M^{2}\left(1+2 K_{\text {onc }}\right)^{2}}{3 M^{2}\left(1+2 K_{\text {onc }}\right)}\right] \sigma_{\mathrm{vmax}}^{\prime}$

where, $M$ : slope of critical state line that can be related to the effective friction angle by:

[A9] $M=\frac{6 \sin \phi^{\prime}}{3-\sin \phi^{\prime}}$ or $\sin \phi^{\prime}=\frac{3 M}{6+M}$

Substituting Eqns. (A3) and (A8) into Eqn. (A1) and rearranging with Eqns. (A2), (A5), and (A9), the isotropic overconsolidation ratio can be found as:

[A10] $R=\frac{3\left(45-12 M+M^{2}\right) \mathrm{OCR}}{(6-M)\left(6+M+2(6-M) \mathrm{OCR}^{\left.\left(\frac{3 M}{6+M}\right)\right)}\right)}$

Figure A1 shows the relationship between the isotropic overconsolidation ratio and the conventional overconsolidation ratio for different values of $M$ (slope of critical state line). It shows that assuming $R$ to be equal to OCR may produce errors up to a $20 \%$, and there is a need to differentiate $R$ from OCR. 


\section{Appendix 2: Notation}

a Radius of cavity at instant time (m)

$a_{0} \quad$ Initial radius of cavity (m)

$B \quad$ Equivalent half width of the plane strain cell (m)

$b_{s} \quad$ Equivalent half width of smear zone in plane strain (m)

$b_{w} \quad$ Equivalent half width of drain (well) in plane strain (m)

$d_{\mathrm{w}} \quad$ Equivalent diameter of vertical drain (m)

$K_{0} \quad$ Coefficient of earth pressure at rest

$K_{0 \text { nc }} \quad K_{0}$ value for normally consolidated clay

$k_{h} \quad$ Horizontal coefficient of permeability for axisymmetry in undisturbed zone $(\mathrm{m} / \mathrm{s})$

$k_{\mathrm{hu}} \quad$ maximum undisturbed zone horizontal permeability $(\mathrm{m} / \mathrm{s})$

$k_{h}^{\prime} \quad$ Horizontal coefficient of permeability for axisymmetry in smear zone $(\mathrm{m} / \mathrm{s})$

$k_{h p} \quad$ Equivalent horizontal coefficient of permeability for plane strain in undisturbed zone $(\mathrm{m} / \mathrm{s})$

$k_{h p}^{\prime} \quad$ Equivalent horizontal coefficient of permeability for plane strain in smear zone $(\mathrm{m} / \mathrm{s})$

$k_{v} \quad$ Vertical coefficient of permeability $(\mathrm{m} / \mathrm{s})$

$n \quad$ Spacing ratio, $R / r_{w}$ or $B / b_{w}$

$p \quad$ Total mean pressure $(\mathrm{kPa})$

$p_{0} \quad$ Total mean pressure $(\mathrm{kPa})$

$p^{\prime} \quad$ Effective mean pressure $(\mathrm{kPa})$

$p_{0}^{\prime} \quad$ Initial effective mean pressure (kPa)

$p_{c}^{\prime} \quad$ Preconsolidation pressure $(\mathrm{kPa})$

$p_{c o}^{\prime}$ Initial preconsolidation pressure $(\mathrm{kPa})$ 
$p_{\mathrm{m}}^{\prime} \quad$ Maximum past mean effective stress $(\mathrm{kPa})$

$q \quad$ Deviator stress $(\mathrm{kPa})$

$q_{\mathrm{m}} \quad$ Deviator stress corresponding to $p_{\mathrm{m}}^{\prime}(\mathrm{kPa})$

$R \quad$ Radius of axisymmetric unit cell (m)

Isotropic overconsolidation ratio

$r \quad$ Final radius of selected soil particle from cavity centre (m)

$r_{0} \quad$ Initial radius of selected soil particle from cavity centre (m)

$r_{m} \quad$ Radius of mandrel (m)

$r_{p} \quad$ Radius of plastic zone (m)

$r_{\mathrm{k}} \quad$ Smear zone permeability ratio

$r_{s} \quad$ Radius of smear zone $(\mathrm{m})$

$r_{w} \quad$ Equivalent radius of vertical drain (m)

$s \quad$ Smear ratio, $r_{s} / r_{w}$ or $b_{s} / b_{w}$

$u \quad$ Pore water pressure $(\mathrm{kPa})$

$w \quad$ Water content $(\%)$

$w_{\max }$ Water content $(\%)$

\section{Greek letters}

$\alpha \quad$ Geometric parameter representing smear in plane strain

$\eta \quad$ Stress ratio

$\kappa \quad$ Slope of recompression line on $v-\ln p^{\prime}$ space

$\Lambda$ Plastic volumetric strain ratio

$\lambda \quad$ Slope of virgin compression line on $v-\ln p^{\prime}$ space

M Slope of critical state line 
$v \quad$ Poison's ratio

$\sigma_{0} \quad$ Initial internal pressure of cavity $(\mathrm{kPa})$

$\sigma_{a}$ Internal pressure of cavity at instant time $(\mathrm{kPa})$

$\sigma_{r} \quad$ Radial stress (kPa)

$\sigma_{r p}$ Radial stress at elastic-plastic boundary ( $\left.\mathrm{kPa}\right)$

$\sigma_{\mathrm{v} 0}^{\prime} \quad$ Initial effective overburden stress $(\mathrm{kPa})$

$\sigma_{\text {vmax }}^{\prime}$ Preconsolidation pressure $(\mathrm{kPa})$

$\sigma_{\theta} \quad$ Circumferential stress $(\mathrm{kPa})$

$v \quad$ Specific volume of soil 


\section{References}

Atkinson J.H. and Potts D.M. 1977. Subsidence above shallow circular tunnels in soft ground. J. Geotech Engng. ASCE, 103(G.T.4): 307-325.

Babu, G.L.S., Pandian, N.S. and Nagaraj, T.S. 1993. A re-examination of the permeability index of clays. Can. Geotech. J. 30: 187-191.

Barron R.A. 1948. Consolidation of fine-grained soils by drain wells. Transactions ASCE, 113: $718-724$.

Cao, L. F., Teh, C. I., and Chang, M. F. 2001. Undrained Cavity Expansion in Modified Cam Clay I: Theoretical Analysis. Geotechnique, 51(4): 323-334.

Collins, I. F. and Yu, H. S. 1996. Undrained Cavity Expansion in Critical State Soils. International Journal for Numerical and Analytical Methods in Geomechanics, 20: 489516.

Hansbo S. 1981. Consolidation of fine-grained soils by prefabricated drains. Proc. $10^{\text {th }}$ International Conference on Soil Mechanics and Foundation Engineering, Stockholm, 3, pp. 677-682.

Indraratna B. and Redana I.W. 1997 Plane strain modeling of smear effects associated with vertical drains. J. Geotech. Engng. ASCE, 123(5): 474-478.

Indraratna B. and Redana I.W. 1998. Laboratory determination of smear zone due to vertical drain installation. J. Geotech \& Geoenv. Engng. ASCE, 124(2): 180-184.

Indraratna B. and Redana I.W. 2000. Numerical modeling of vertical drains with smear and well resistance installed in soft clay. Can. Geotech. J. 37(1): 133-145.

Indraratna B., Bamunawita, C. and Khabbaz, H. 2004 Numerical modelling of vacuum preloading and field applications. Can. Geotech. J. 41(6): 1098-1110.

Jaky J. 1944. The coefficient of earth pressure at rest. J. for Society of Hungarian Architects and Engrs. 8:355-358.

Mayne P.W. and Kulhawy F.H. 1982. $\mathrm{K}_{0}$ - OCR relationship in soils. J. Geotec. Engng. ASCE, 108(6): 851-872. 
Onoue, A. 1988. Consolidation by vertical drains taking well resistance and smear into consideration. J. Soils and Foundations, 28(4): 165-174.

Queensland Department of Transport. 1991. Sunshine Motorway Stage 2 - Area 2 Geotechnical Investigation. Materials and Geotechnical Services Branch, June, R1765.

Queensland Department of Transport. 1992. Sunshine Motorway Stage 2 - Interim Report on the Performance of the Trial Embankment Area 2A (Ch 28490-28640). Materials and Geotechnical Services Branch, July, R1802.

Sathananthan I. 2005. Modelling of vertical drains with smear installed in soft clay. University of Wollongong, Australia, PhD thesis.

Sharma J.S. and Xiao D. 2000. Characterization of a smear zone around vertical drains by large-scale laboratory tests. Can. Geotech. J. 37(6): 1265-1271.

Tavenas, F., Mieussens, C., and Bourges, F. 1979. Lateral displacements in clay foundations under embankments. Can. Geotech. J. 16: 532-550.

Tavenas, F., Jean, P., Leblond, P. and Leroueil, S. 1983a. The permeability of natural soft clays, Part I: Methods of laboratory Permeability measurement. Can., Geotech., J., 20: 629-644.

Tavenas, F., Jean, P., Leblond, P. and Leroueil, S. 1983b. The permeability of natural soft clays, Part II: Permeability characteristics. Can., Geotech., J., 20: 645-660.

Taylor D.W. 1948. Fundamentals of Soil Mechanics. John Wiley and Sons Inc., New York, $700 \mathrm{p}$.

Vesic, A. S. 1972. Expansion of cavities in in®nite soil mass. J. Soil Mech. Found. Div., ASCE 98(SM3): 265-290.

Yu, H.S. 2000. Cavity Expansion Methods in Geomechanics. Kluwer Academic Publishers. $404 p$. 
Table 1 Cam-clay parameters of clay specimen used in large-scale consolidation test

\begin{tabular}{|c|c|c|c|c|c|c|}
\hline Clay type & $\lambda$ & $\kappa$ & $\mathrm{M}$ & $v_{\mathrm{o}}$ & $v$ & $\gamma_{\mathrm{s}}$ \\
\hline $\begin{array}{c}\text { Moruya clay } \\
\text { (Indraratna et al., 2004) }\end{array}$ & 0.15 & 0.05 & 1.1 & 2.8 & 0.25 & 18 \\
\hline $\begin{array}{c}\text { Kaolin clay } \\
\text { (Sharma and Xiao, 2000) }\end{array}$ & 0.24 & 0.02 & 1.03 & 2.8 & 0.23 & 16 \\
\hline
\end{tabular}

Table 2 Modified Cam-clay parameters used in the finite element analysis

\begin{tabular}{cccccccccc}
\hline \hline Depth (m) & Soil type & $M$ & $\lambda /\left(1+\mathrm{e}_{0}\right)$ & $\kappa /\left(1+\mathrm{e}_{0}\right)$ & $v$ & $e_{0}$ & $\begin{array}{c}\gamma_{\mathrm{s}} \\
\mathrm{kN} / \mathrm{m}^{3}\end{array}$ & $\begin{array}{c}\text { Average } p_{c}^{\prime} \\
(\mathrm{kPa})\end{array}$ \\
\hline $0.0-2.5$ & $\begin{array}{c}\text { Silty clay } \\
(\mathrm{OCR}=1.6)\end{array}$ & 1.20 & 0.19 & 0.019 & 0.30 & 1.6 & 16.4 & 20 \\
& & & & & & & & & \\
$2.5-5.0$ & Soft silty clay & 1.20 & 0.63 & 0.063 & 0.30 & 2.2 & 13.7 & 31 \\
$5.0-11$ & Silty clay & 1.18 & 0.19 & 0.019 & 0.3 & 1.8 & 15.9 & 66 \\
\hline
\end{tabular}


Table 3 Equivalent Plane Strain permeabilities of embankment sections

\begin{tabular}{|c|c|c|c|c|c|}
\hline \multirow{2}{*}{$\begin{array}{l}\text { Depth } \\
\text { (m) }\end{array}$} & $\begin{array}{c}\text { Section B }\left(10^{-9} \mathrm{~m} / \mathrm{s}\right) \\
\text { (No drains) }\end{array}$ & \multicolumn{2}{|c|}{$\begin{array}{c}\text { Section A }\left(10^{-9} \mathrm{~m} / \mathrm{s}\right) \\
\text { (Drains @ } 1 \mathrm{~m} \text { spacing) }\end{array}$} & \multicolumn{2}{|c|}{$\begin{array}{c}\text { Section C }\left(10^{-9} \mathrm{~m} / \mathrm{s}\right) \\
\text { (Drains @ } 2 \mathrm{~m} \text { spacing) }\end{array}$} \\
\hline & $k_{h}$ & $\begin{array}{c}k_{h p} \\
\text { (Eq. 5) }\end{array}$ & $\begin{array}{c}k_{h p}^{\prime}\left(x=b_{\mathrm{w}}\right) \\
(\text { Eq. 6) }\end{array}$ & $\begin{array}{c}k_{h p} \\
\text { (Eq. 5) }\end{array}$ & $\begin{array}{c}k_{h p}^{\prime}\left(x=b_{\mathrm{w}}\right) \\
(\text { Eq. 6) }\end{array}$ \\
\hline $\begin{array}{c}0.0-2.5 \\
\text { (Silty clay) }\end{array}$ & 9.72 & 3.29 & 1.65 & 2.43 & 1.21 \\
\hline $\begin{array}{c}2.5-5.0 \\
\text { (Soft silty clay) }\end{array}$ & 0.34 & 0.11 & 0.06 & 0.09 & 0.05 \\
\hline $\begin{array}{c}5.0-11 \\
\text { (Silty clay) }\end{array}$ & 0.42 & 0.14 & 0.07 & 0.11 & 0.06 \\
\hline
\end{tabular}




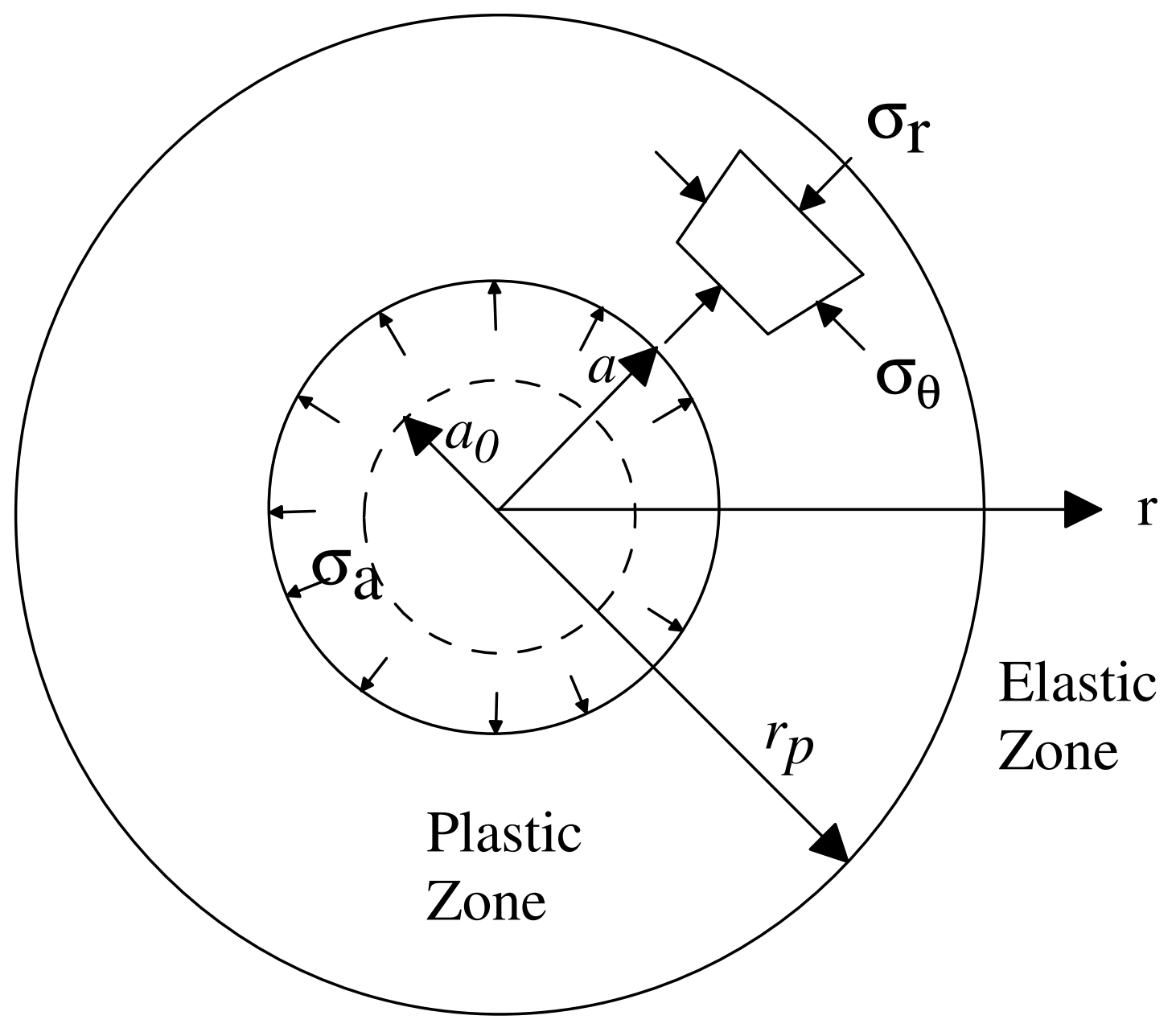

Figure 1 Expansion of a Cavity (Yu, 2000) 


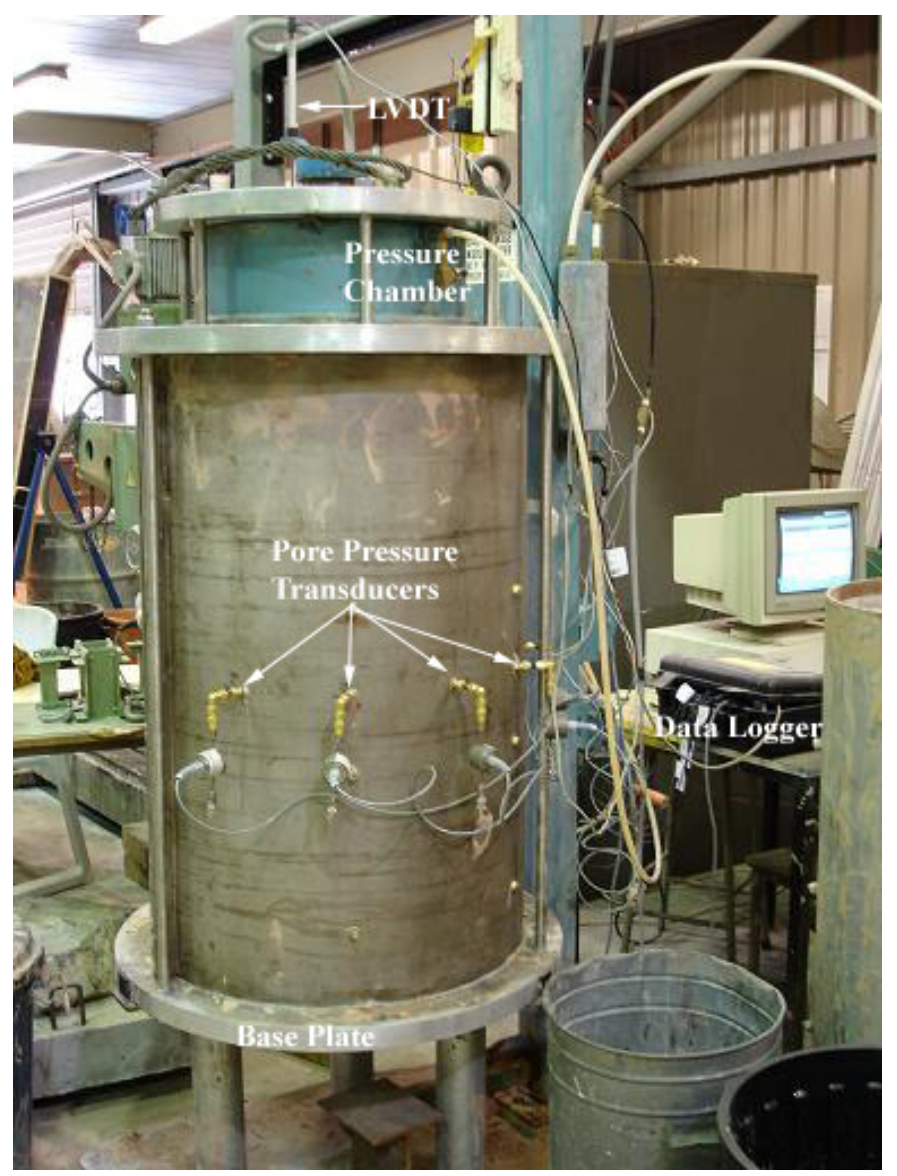

(a)

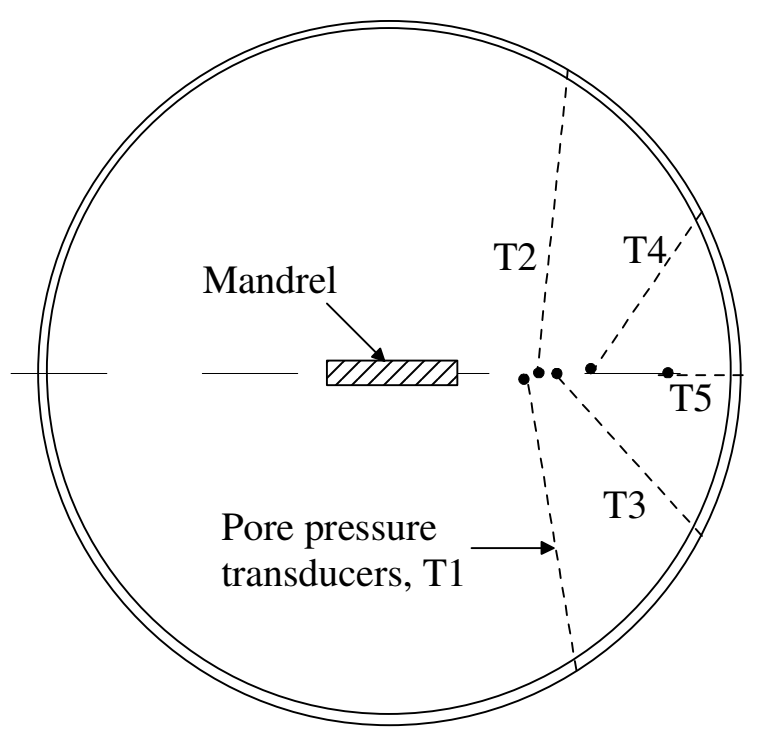

(b)

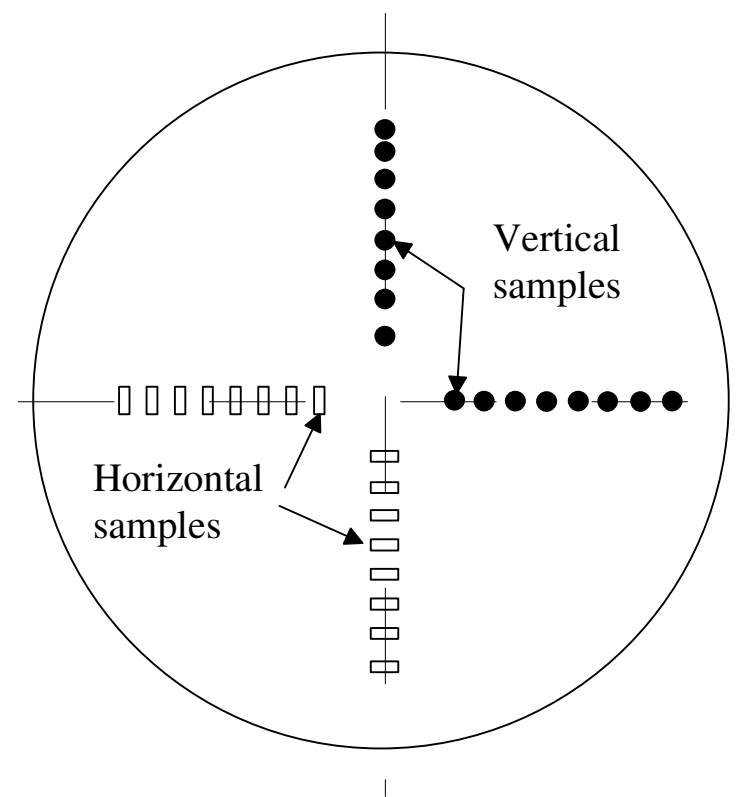

(c)

Figure 2 (a) Large-scale radial drainage consolidometer, (b) Location of pore pressure transducers, and (c) Location of cored samples 


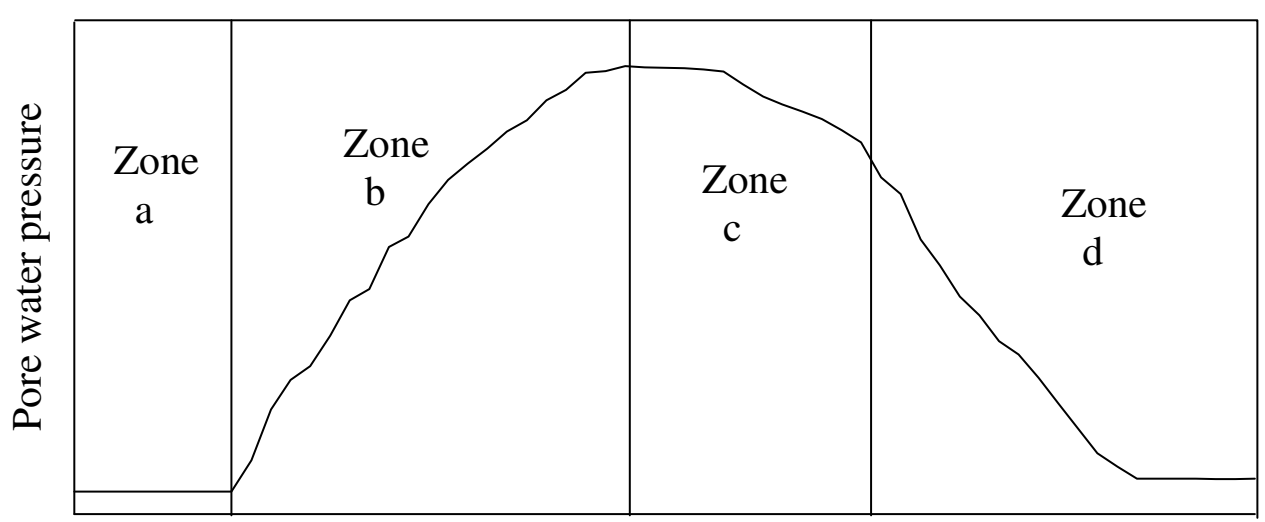

Time

Zone a: Before mandrel penetration

Zone b: Pore pressure increase as the mandrel approaches the location of pore pressure transducer

Zone c: Mandrel passes the location of transducer

Zone d: Mandrel withdrawal

Figure 3 Typical pore pressure variation during mandrel installation 


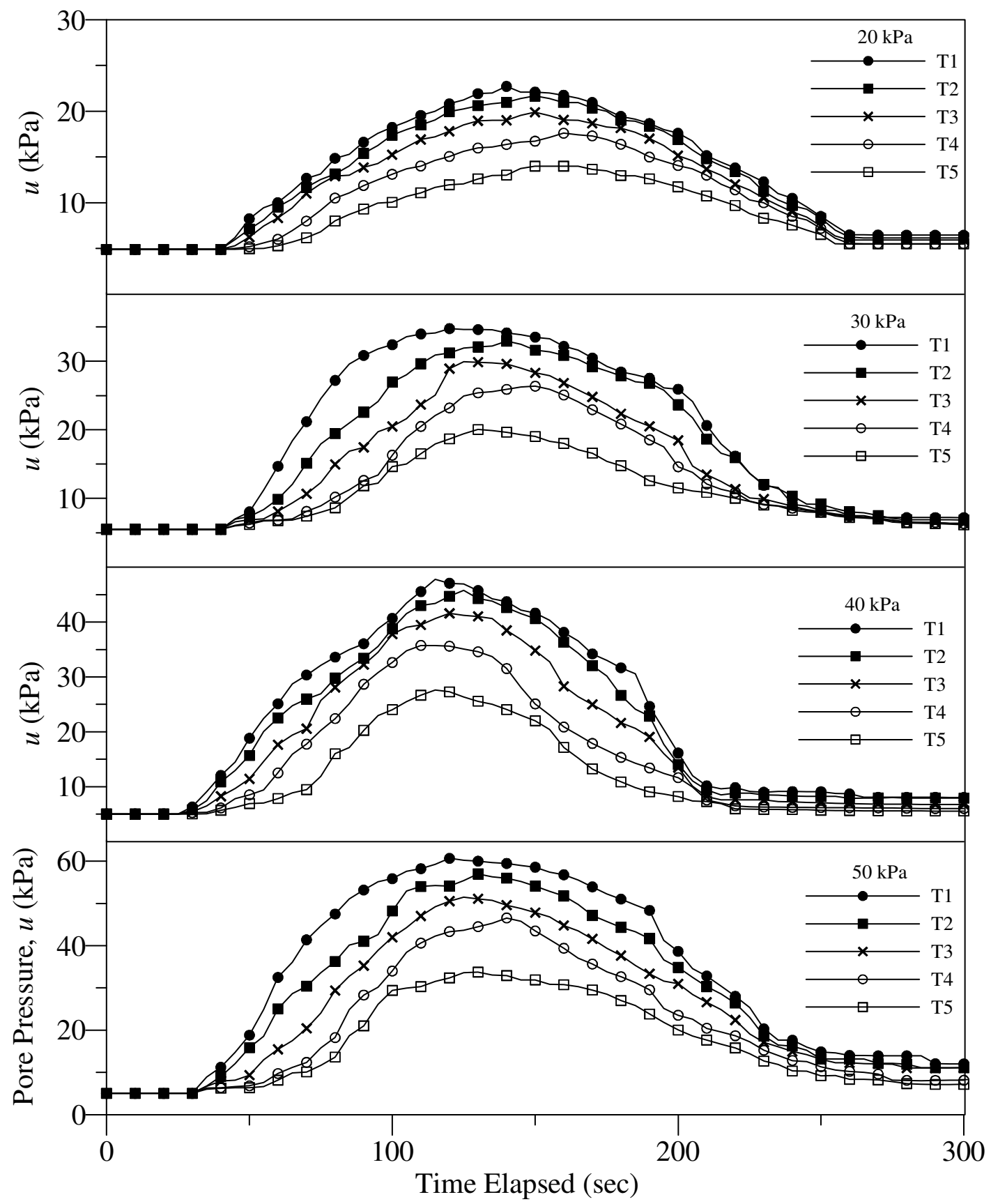

Figure 4 Pore pressure variations during mandrel installation for different initial surcharge pressure 


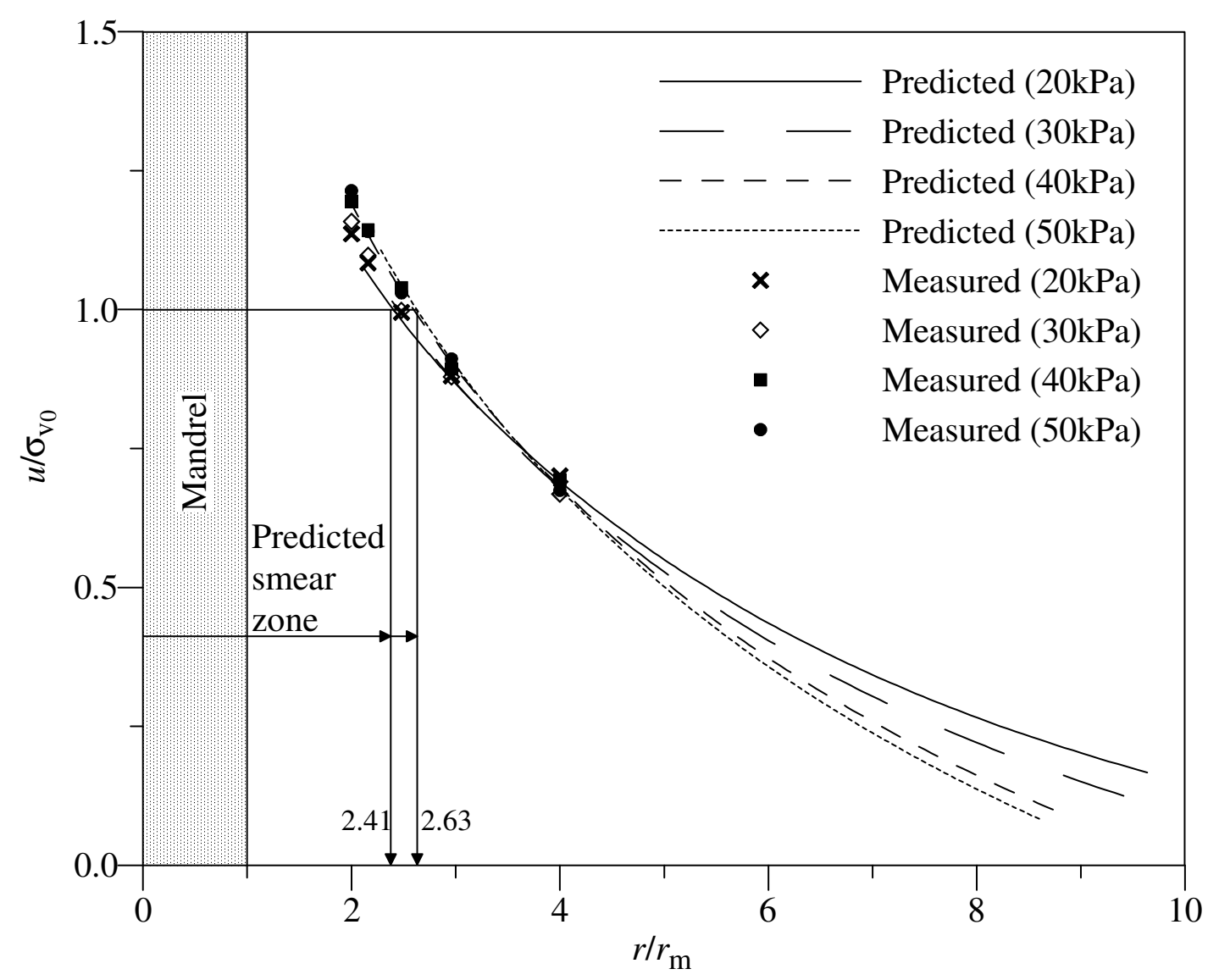

Figure 5 Comparison of normalized pore water pressure variation 


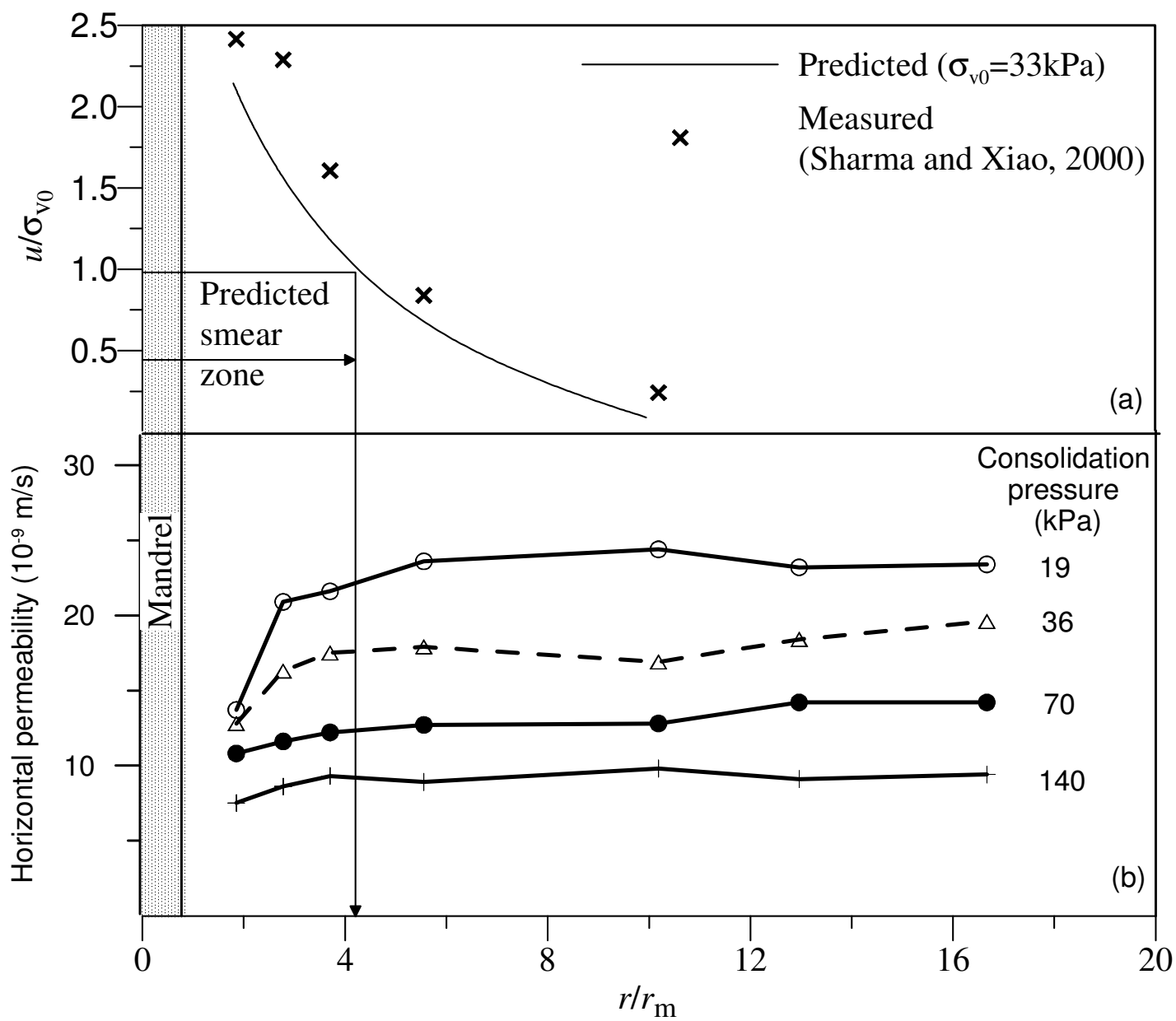

Figure 6 (a) Comparison of normalized pore water pressure variation and (b) radial permeability variation 


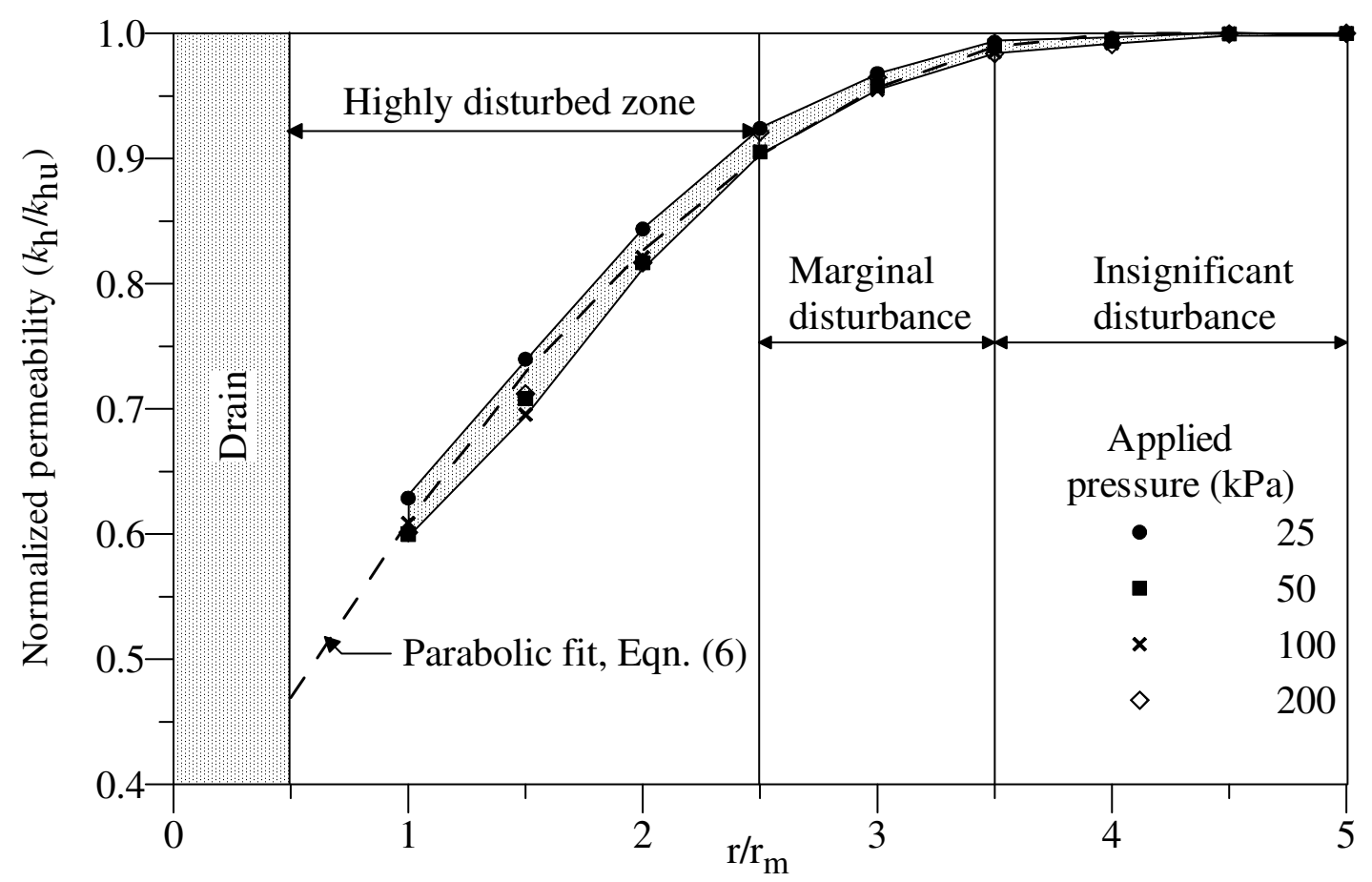

(a)

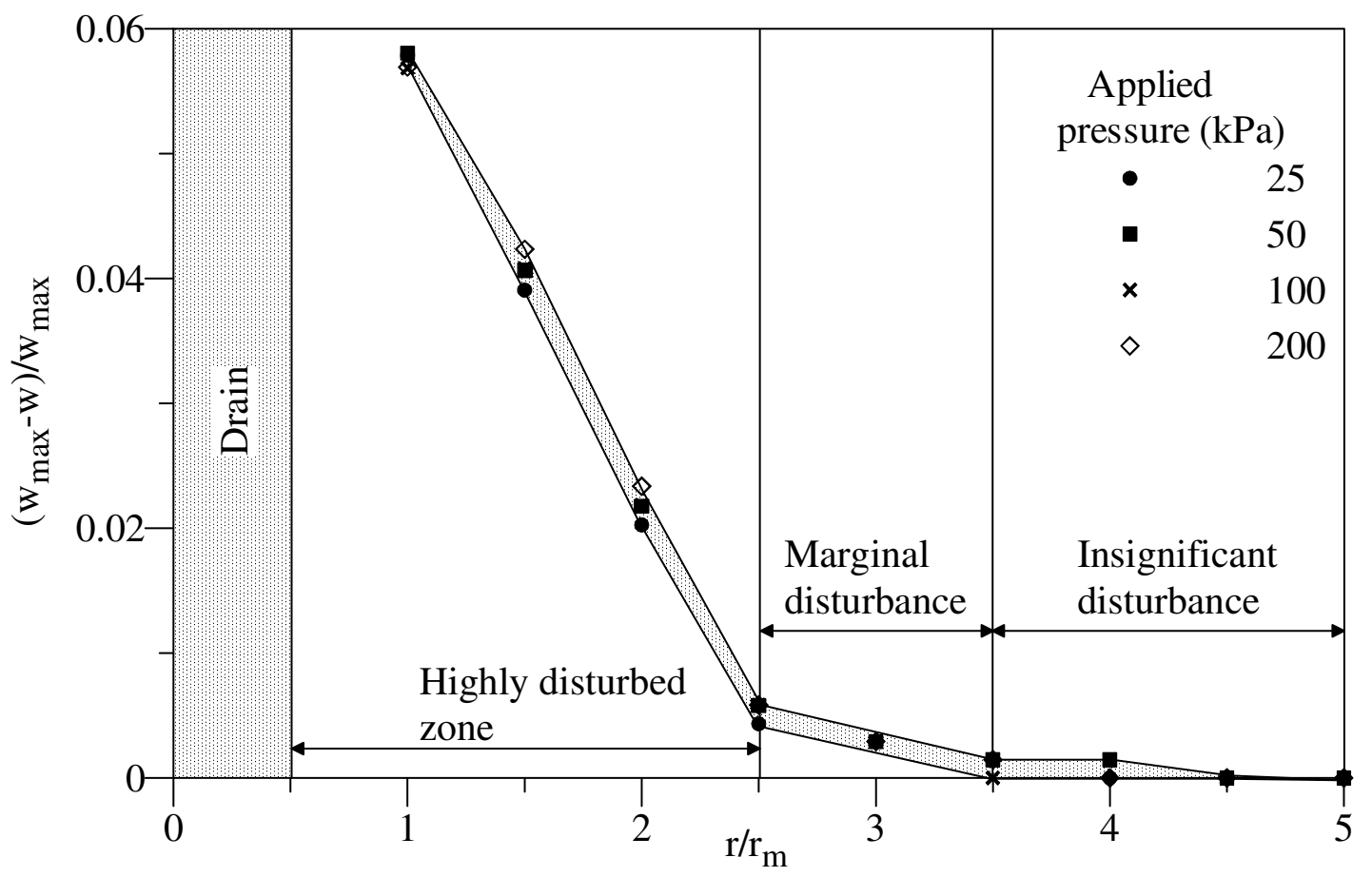

(b)

Figure 7 Variation of (a) normalized lateral permeability, and (b) normalized water content reduction, with radial distance 


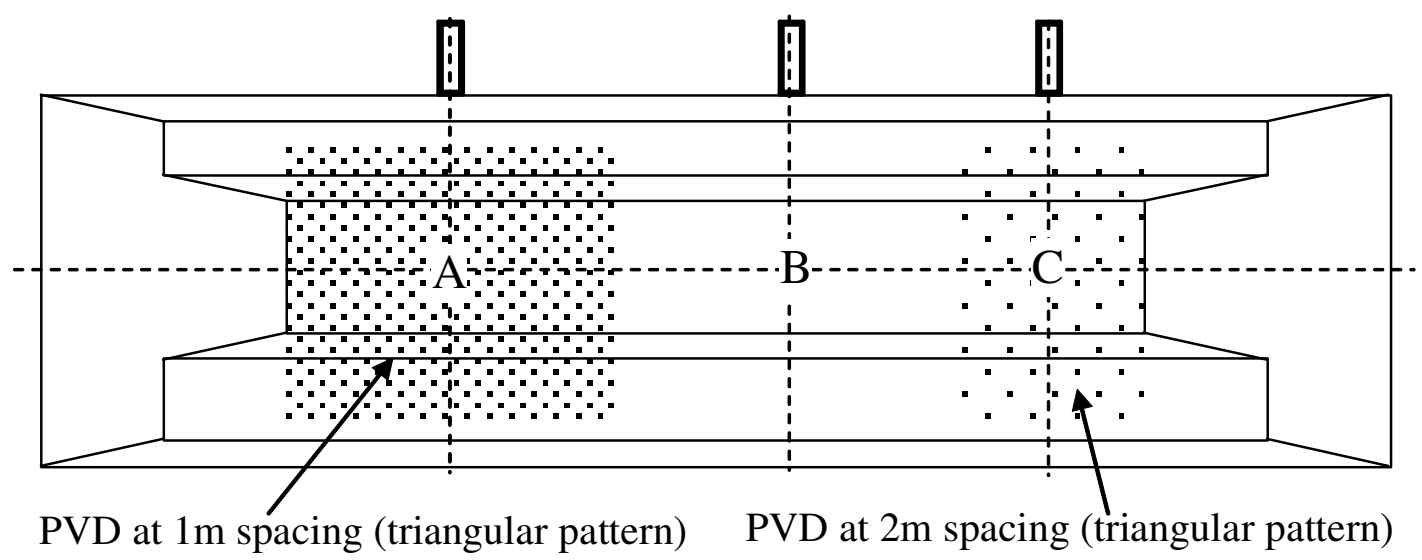

(a)

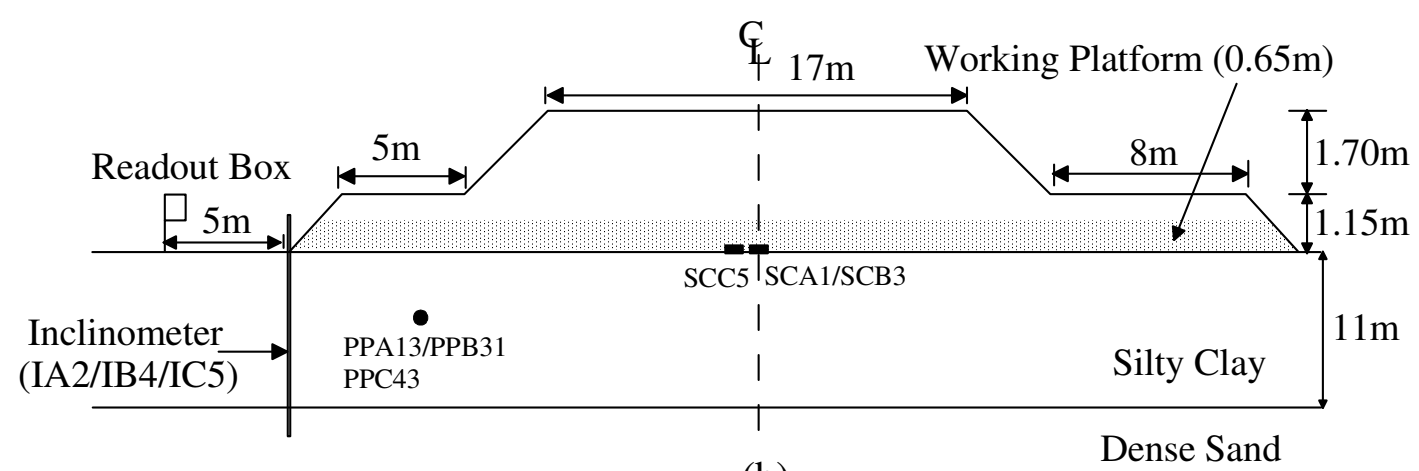

(b)

Figure 8 (a) Plan view of trial embankment, and (b) Typical cross-section of embankment with selected instrumentation points (QDMR, 1992) 


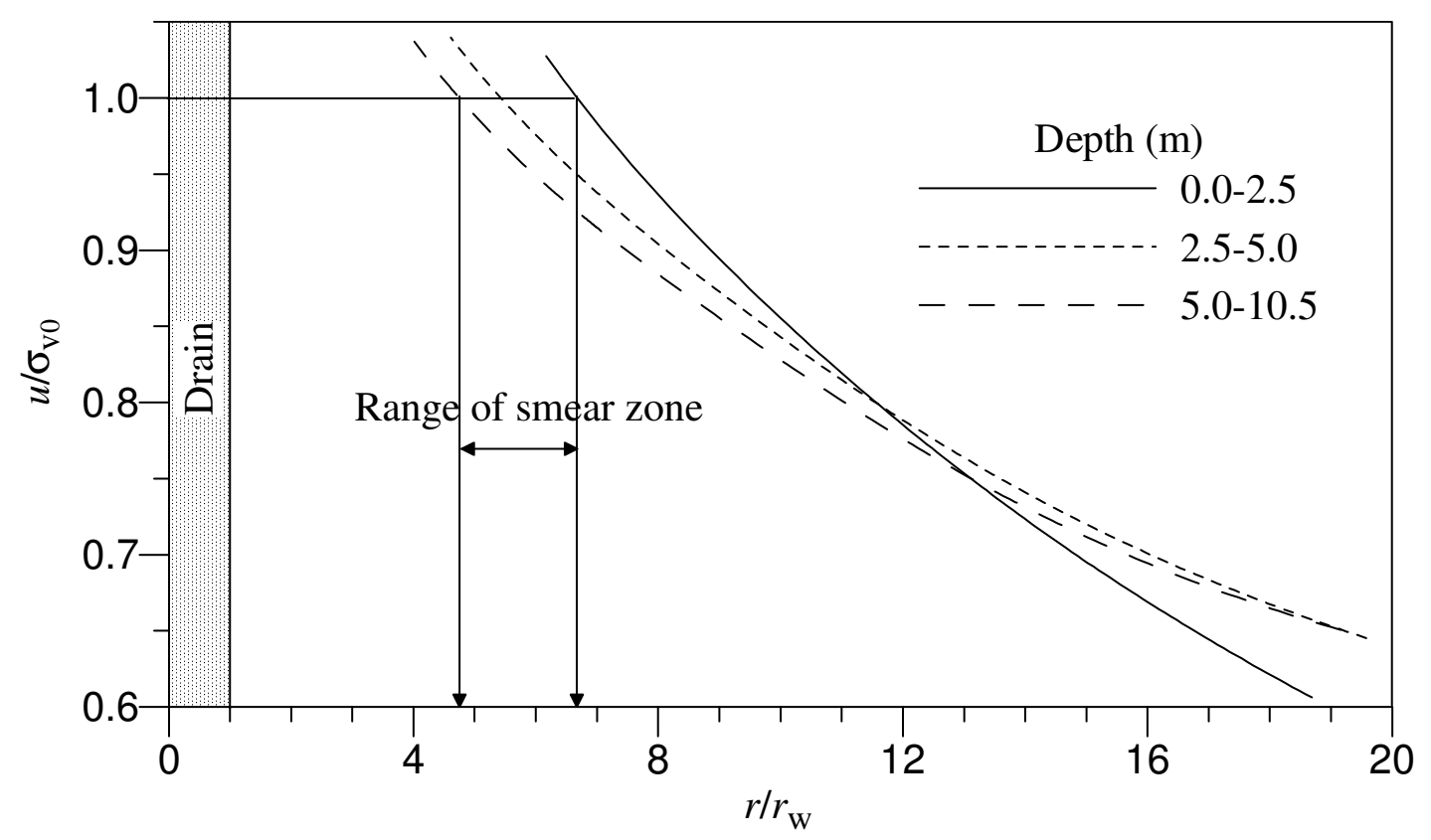

(a)

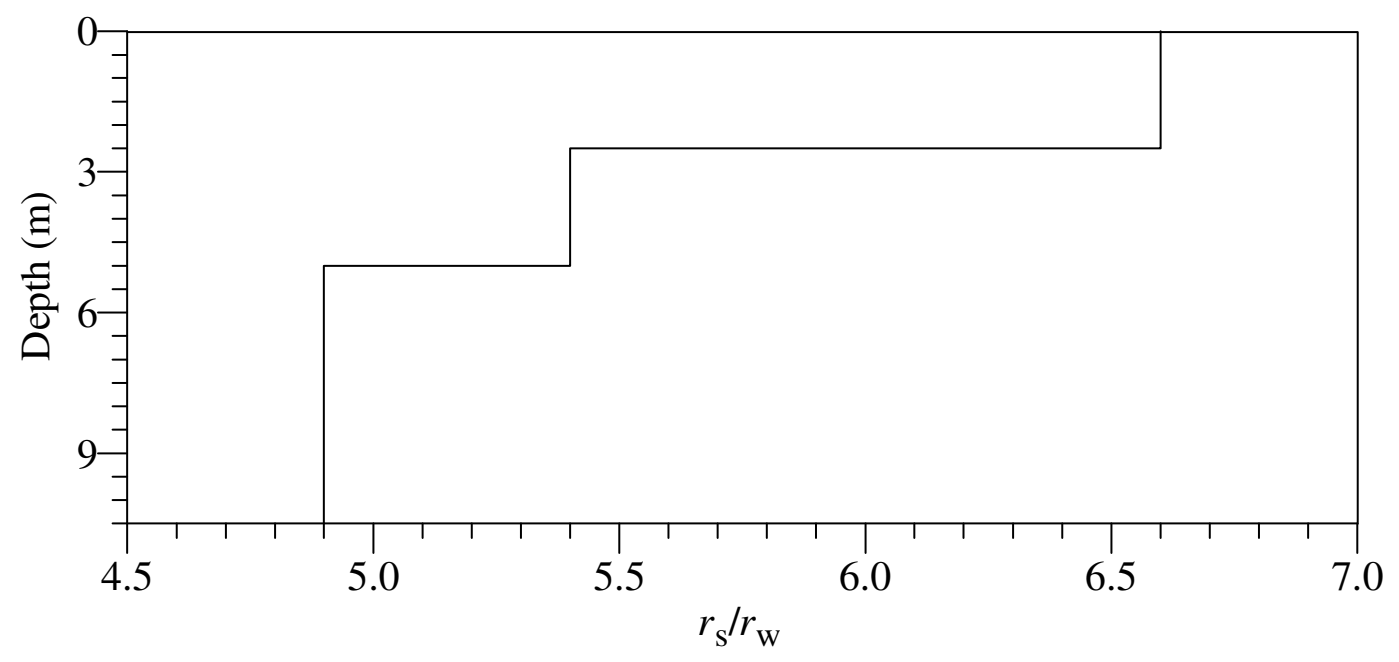

(b)

Figure 9 (a) Normalised pore water pressure variation with radial distance, and (b) Variation of the extent of the smear zone with depth 


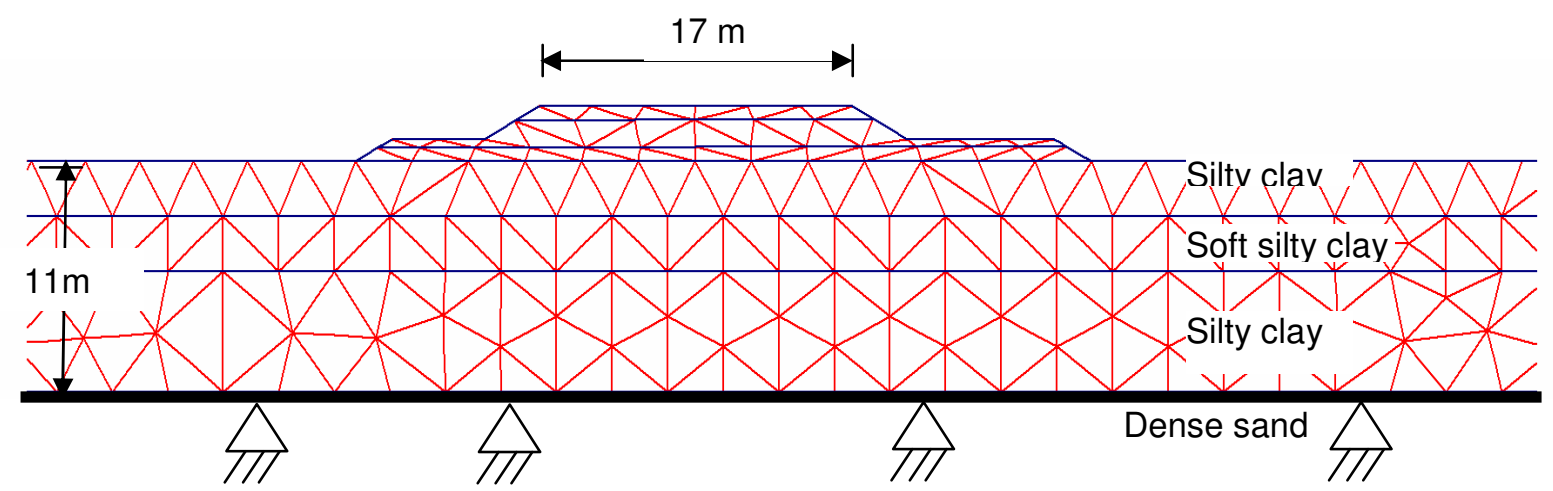

Figure 10 Finite element mesh used to analyse Section B (Note: this figure shows only the embankment region. The outer boundaries of the FEM analysis are 150m away from the centreline)

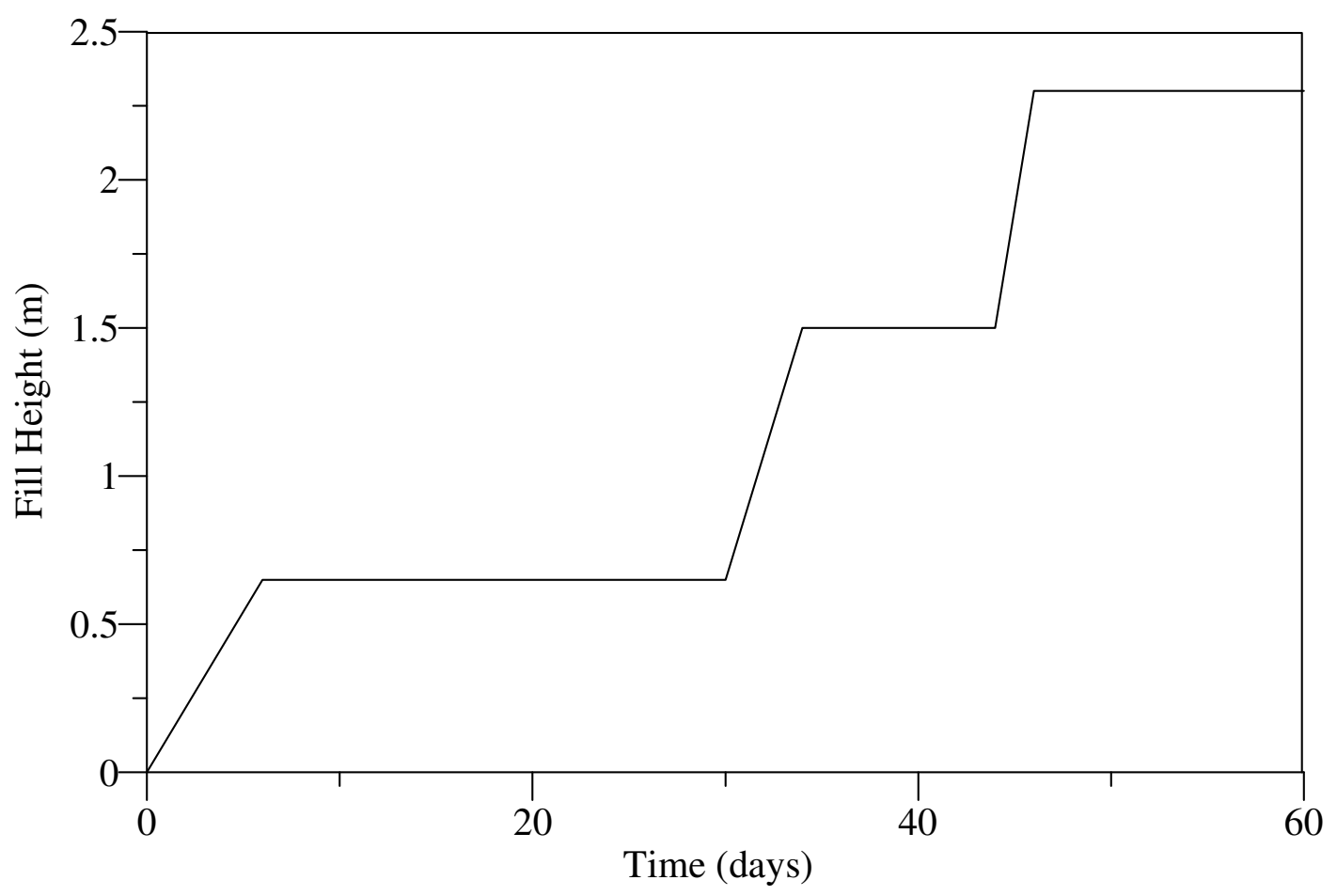

Figure 11 Construction history of the trial embankment 


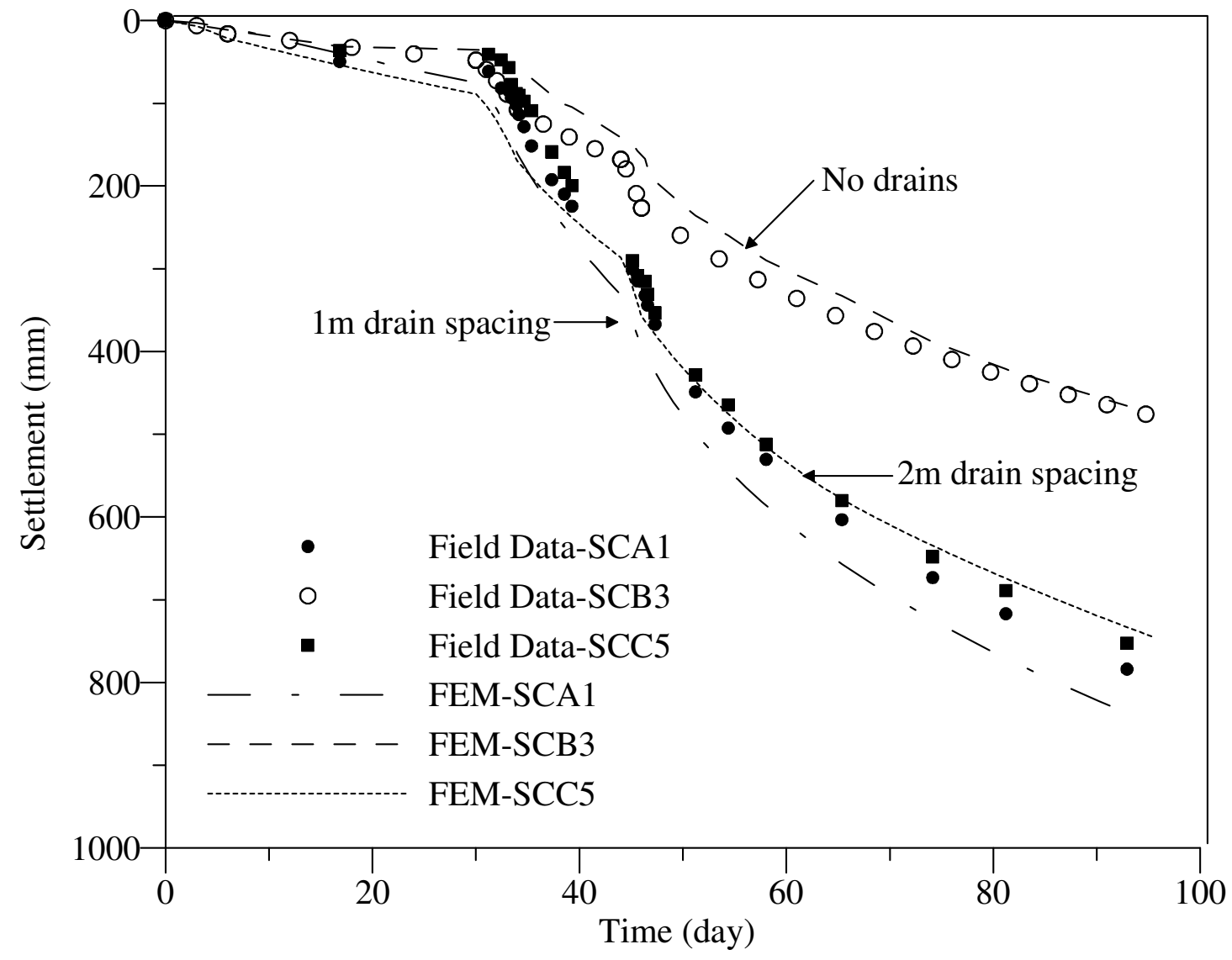

Figure 12 Centreline settlement of Sections A, B and C 


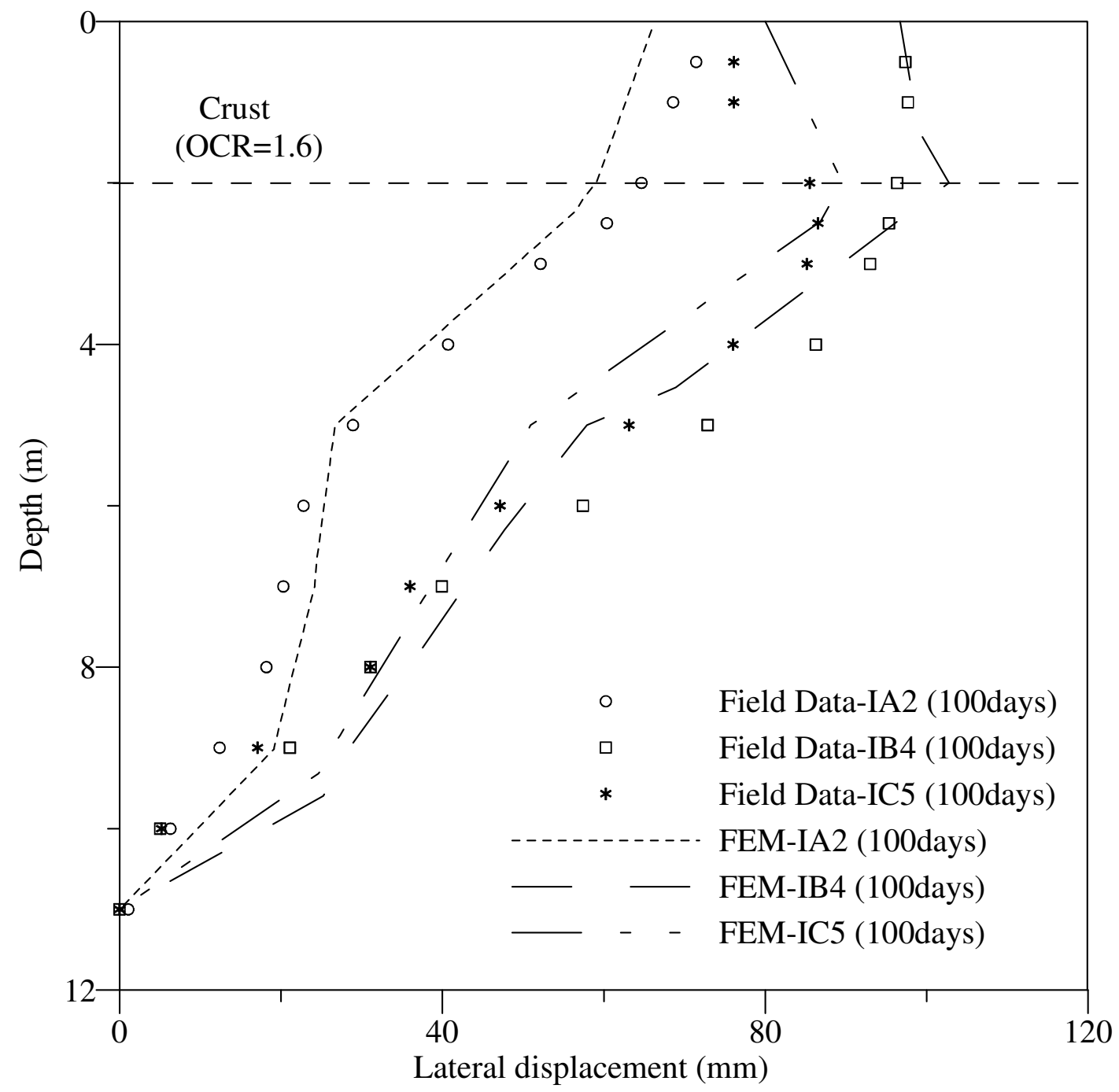

Figure 13 Lateral displacement profiles at the toe $5 \mathrm{~m}$ berm of the embankment sections 


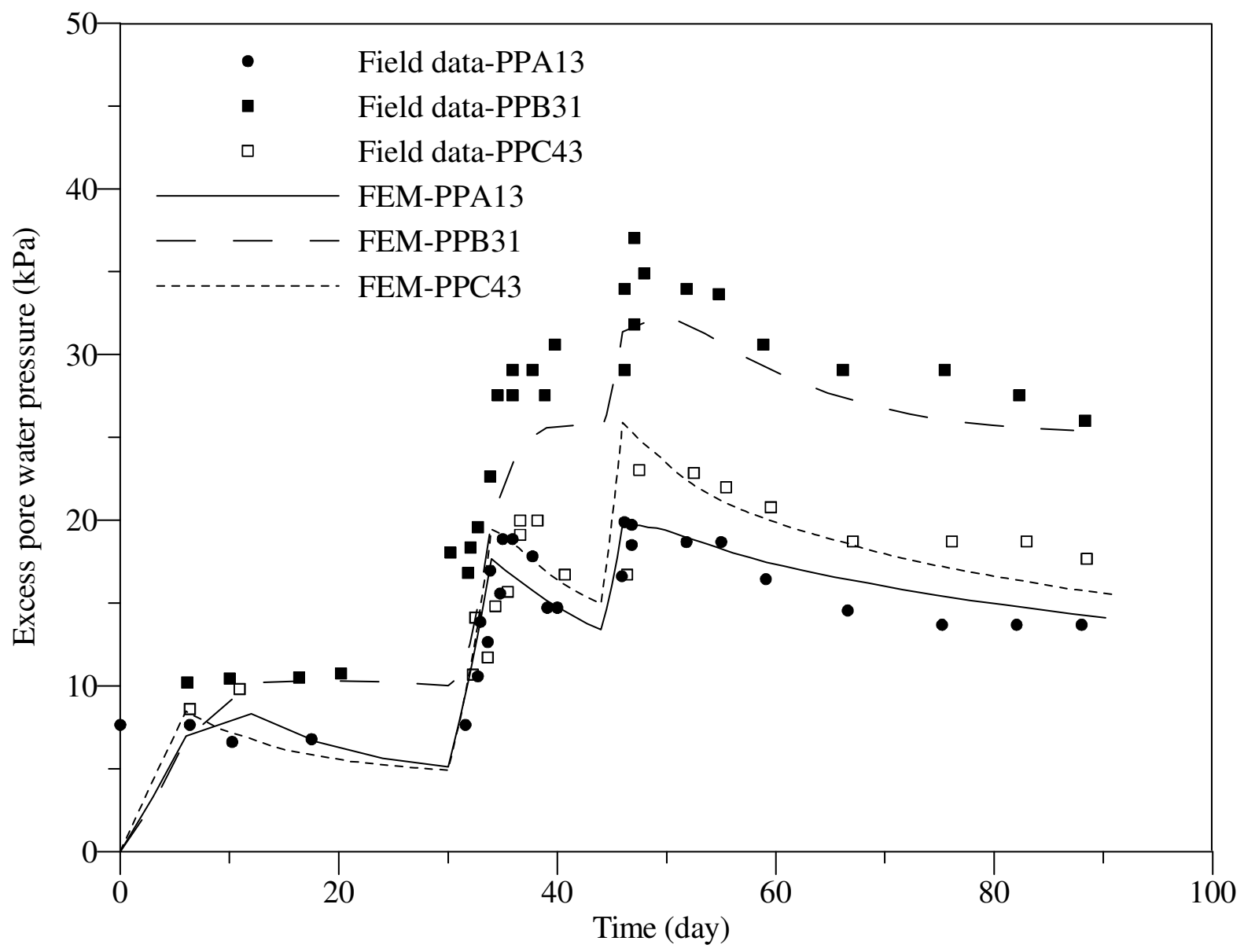

Figure 14 Excess pore pressure variation with time beneath the middle of the berm $5 \mathrm{~m}$ 


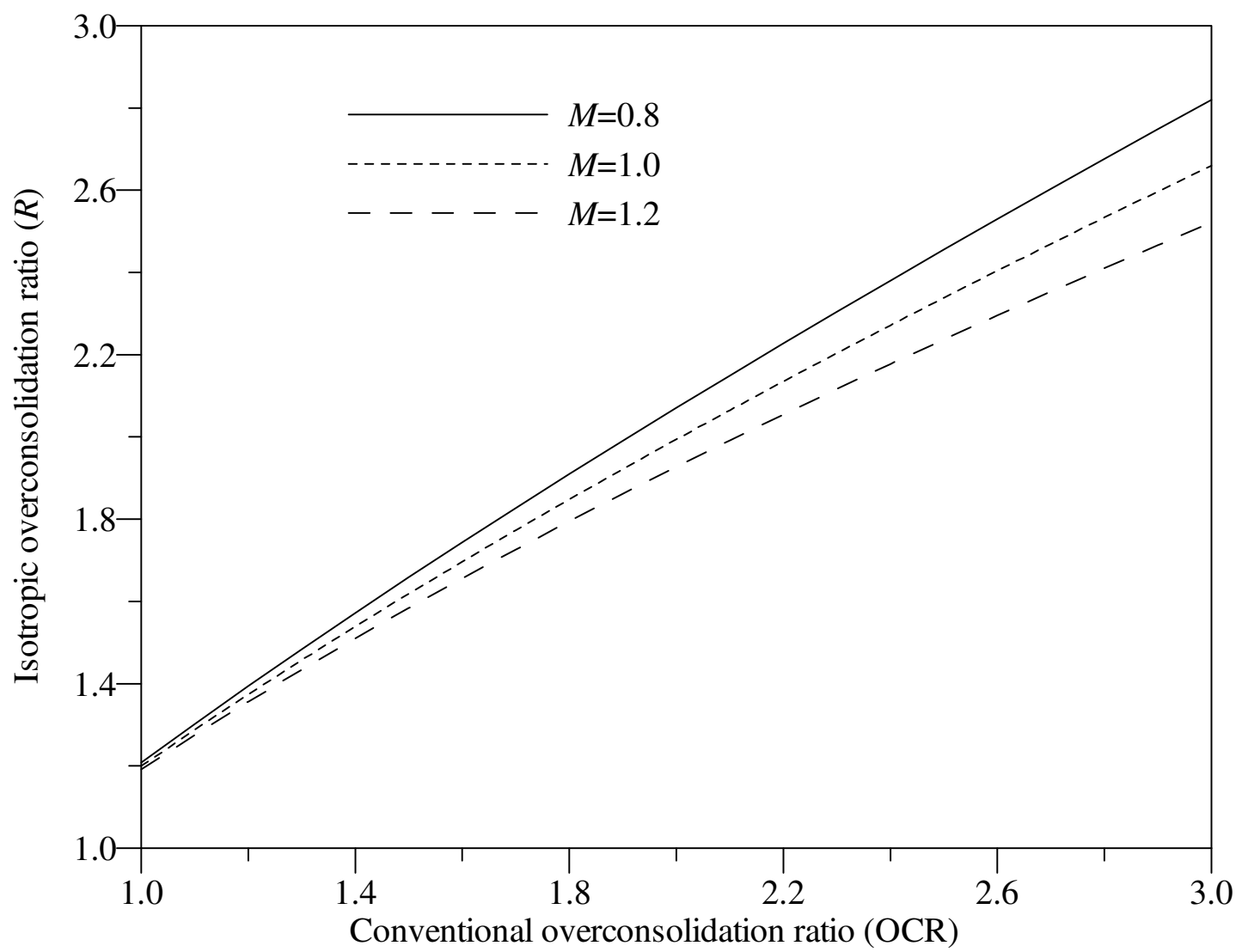

Figure A1 Variation of the isotropic and conventional overconsolidation ratio with slope of critical state line 